Maurer School of Law: Indiana University

Digital Repository @ Maurer Law

2001

\title{
Equity and the Article I Court: Is the Tax Court's Exercise of Equitable Powers Constitutional?
}

Leandra Lederman

Indiana University Maurer School of Law, Ilederma@indiana.edu

Follow this and additional works at: https://www.repository.law.indiana.edu/facpub

Part of the Courts Commons, Taxation-Federal Commons, and the Tax Law Commons

\section{Recommended Citation}

Lederman, Leandra, "Equity and the Article I Court: Is the Tax Court's Exercise of Equitable Powers Constitutional?" (2001). Articles by Maurer Faculty. 494.

https://www.repository.law.indiana.edu/facpub/494

This Article is brought to you for free and open access by the Faculty Scholarship at Digital Repository @ Maurer Law. It has been accepted for inclusion in Articles by Maurer Faculty by an authorized administrator of Digital Repository @ Maurer Law. For more information, please contactrvaughan@indiana.edu.

\section{$\Psi$}

LAW LIBRARY

INDIANA UNIVERSITY Maurer School of Law
Bloomington 


\section{FLORIDA TAX REVIEW}

Equity and the Article I Court:

Is the Tax Court's Exercise of Equitable Powers Constitutional?

Leandra Lederman*

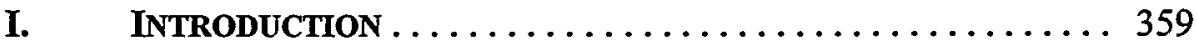

II. THE ROLE AND POWERS OF ARTICLE I COURTS . . . . . . . 362

A. The Constitutional Role of Legislative Courts ...... 362

B. The Tax Court as an Article I Court ............ 365

C. The Powers of Article I Courts ............. 368

III. THE ORIGINS OF EQUITY AND ITS USE IN ARTICLE I COURTS 371

A. A History of Equity . ................ 371

1. The Development of Equity in England ..... 372

2. Equity in the United States ............ 374

B. Equity in Article I Courts ................ 375

1. In General ..................... 375

2. Equity in the Tax Court ............ 378

a. The Equitable Recoupment Saga .... 379

b. Equitable Estoppel ............. 388

c. Equitable Innocent Spouse Relief . . . 390

IV. The TAX CouRT: Does IT HAVE EQUTTABLE PoWERS? . . . 393

A. The Parallelism Fallacy ............... 396

B. Possible Sources of Power to Apply Equitable Principles

1. Four Categories of Cases ............ 399

2. The Indebitatus Assumpsit Ancestry of Tax Refund

Claims ...................... 401

a. The Tax Refund Action and the Tax Court

Overpayment Claim ........... 402

* Associate Professor, George Mason University School of law. I am extremely grateful to Terry Chorvat, David Hyman, Matthew Mirow, and David Richardson for their helpful suggestions and comments on various aspects of this article, and to Judge Herbert Chabot, Stephen Mazza and Dan Shaviro for their comments on prior drafts. I would also like to acknowledge the valuable insights of Judge James Halpern, Marty McMahon, and other participants in the Tax Section's Teaching Tax Committee program at the American Bar Association's 2001 annual meeting, and of Kent Syverud and other participants in the Southeastern Association of American Law Schools' 2000 annual meeting. I would also like to thank Larry Lederman and Mark Newton for helpful conversations about the topic of this article; C. Drew Hoster for his excellent research assistance; Femi Cadmus for her research support; and George Mason University School of Law and its Law and Economics Center for financial support. 
b. The Quasi-Equitable History of Indebitatus Assumpsit .............. 406 V. ConClusion 411 
"Relieve the judges from the rigour of text law, and permit them, with pretorian discretion, to wander into it's equity, and the whole legal system becomes incertain."

"Tax law is not based on equity and arguments of equity have little force."***

\section{INTRODUCTION}

To most lawyers, the "federal courts" are the courts created under Article III of the United States Constitution. ${ }^{1}$ However, the federal courts also include the United States Tax Court, the United States Court of Federal Claims, the bankruptcy courts, and the territorial courts - all "legislative courts" created by Congress under Article I of the Constitution. Several of these Article I courts have important jurisdiction and large dockets, and issue influential opinions with precedential value. ${ }^{2}$ Yet, scholars typically have not paid much attention to legislative courts other than the bankruptcy courts, which are courts adjunct to the Article III district courts. Since 1988, when Professor Richard Fallon of Harvard Law School published his important article, "Of Legislative Courts, Administrative Agencies, and Article III,"3 little has been published on the features and limitations of Article I courts.

** Letter from Thomas Jefferson to Philip Mazzei (Nov. 28, 1785), in 9 The Papers of Thomas Jefferson 71 (J. Boyd ed. 1954) (original spelling retained).

*** Polos v. United States, 231 Ct. Cl. 929, 932 (1982) (citing Commissioner v. Kowalski, 434 U.S. 77, 95 (1977)).

1. See Judith Resnik, Housekeeping: the Nature and Allocation of Work in Federal Trial Courts, 24 Ga. L. Rev. 909, 910 (1990) ("the words 'the federal courts' and 'the federal judiciary' are still commonly used to refer to that set of judges who have life tenure ('Article III judges'), but the equation is imprecise. 'The federal courts' are also populated by other 'federal judges' - who work within the judicial branch but who are creatures of congressional legislation.").

2. The United States Tax Court (Tax Court) is an example. The Tax Court is a national court that sits in numerous cities nationwide, and has a multi-billion dollar docket. In fiscal year 1999 , for example, $\$ 32.8$ billion were in dispute in pending Tax Court cases. By contrast, $\$ 2.7$ billion were in dispute in tax cases in the Court of Federal Claims, and $\$ 2.6$ billion were in dispute in tax cases in the District Courts. American Bar Association Tax Section Court Procedure Committee. January 2001 Report of Office of Chief Counsel, Internal Revenue Service, at 2 [hereinafter, Report to ABA].

Tax Court cases are often cited by Article III courts. See, e.g., GE v. Commissioner, 245 F.3d 149 (2d Cir. 2001) (citing, among other Tax Court cases, Central Pa. Sav. Ass'n v. Commissioner, 104 T.C. 384, 392 (1995); Sim-Air, USA, Ltd. v. Commissioner, 98 T.C. 187, 192 (1992)); Estate of O'Neal v. United States, 81 F. Supp. 2d 1205 (N.D. Ala. 1999) (citing, among others, Quirk v. Commissioner, 15 T.C. 709 (1950), aff'd, 196 F.2d 1022 (5th Cir. 1952); Holmes v. Commissioner, 47 T.C. 622, 627 (1967); Estate of Stein v. Commissioner, 40 T.C. 275 (1963); Estate of Trompeter v. Commissioner, 75 T.C. Memo (CCH) 1653 (1980)).

3. 101 Harv. L. Rev. 916 (1988). 
Perhaps legislative courts are overlooked because they have no clear place in the study of constitutional law; ${ }^{4}$ it is Article III of the Constitution that grants the judicial power of the United States to the United States Supreme Court (Supreme Court) and inferior courts such as the United States Courts of Appeals and the District Courts. ${ }^{5}$ Yet Article I courts perform the traditional judicial function of resolving controversies by applying the law to the facts and rendering an opinion. In fact, they resemble Article III courts in most respects, except that their judges lack the salary and tenure protections of Article III. ${ }^{6}$

Despite the superficial resemblance to Article III courts, Article I courts lack other features key to judicial power. For example, Article III expressly provides courts with jurisdiction in both law and equity; Article I does not mention law or equity and does not even specifically grant Congress the power to create any court. In 1938, the adoption of the Federal Rules of Civil Procedure $^{7}$ eliminated the distinction between law and equity in Article III courts, but those rules do not apply in the United States Tax Court. ${ }^{8}$ Does the Tax Court have equitable powers? Should it? Given the importance of the Article I courts in adjudicating public rights, ${ }^{9}$ it is surprising how uncertain and

4. Cf. Eric Bruggink. A Modest Proposal, 28 Pub. Cont. L.J. 529, 542 (1999) (a "consequence of being an Article $I$ court is the lack of any clear location for the court in the Government's organizational chart").

5. See U.S. Const. art. III. $\S 1$ ("The judicial Power of the United States, shall be vested in one supreme Court, and in such inferior Courts as the Congress may from time to time ordain and establish ....").

6. See id. ("The Judges, both of the supreme and inferior Courts, shall hold their Offices during good Behavior, and shall, at stated Times, receive for their Services, a Compensation, which shall not be diminished during their Continuance in Office.").

7. See Fed. R. Civ. P. 2, 18; see also Ross v. Bernhard, 396 U.S. 531, 539 (1970); John R. Kroger, Supreme Court Equity, 1789-1835, and the History of American Judging, 34 Hous. L. Rev. 1425, 1430 (1998). The Court of Federal Claims has a rule similar to rule 2 of the Federal Rules of Civil Procedure. See Ct. Fed. Cl. 2 ("There shall be one form of action to be known as a "civil action."”).

8. "The United States Tax Court is the paradigm of an Article I court and the quintessential specialty court." Richard B. Hoffman \& Frank P. Cihlar, Judicial Independence: Can it be Without Article III?, 46 Mercer L. Rev. 863, 869 (1995).

9. See Ex Parte Bakelite Corp., 279 U.S. 438, 451-52 (1929) ("Legislative courts ... may be created as special tribunals to examine and determine various matters, arising between the government and others, which from their nature do not require judicial determination and yet are susceptible of it. ... Conspicuous among such matters are claims against the United States. These may arise in many ways and may be for money, lands or other things.").

In fiscal year 1999, for example, the Tax Court had a docket of approximately 21,900 cases, which was lower than in prior years. See Report to ABA, supra note 2, at 3. For the same year, the District Courts had approximately 1,200 docketed tax cases, and the Court of Federal Claims had approximately 700. See Report to ABA, supra note 2, at 3. District Court suits include cases over which the Tax Court does not have jurisdiction, such as certain types of excise tax cases.

The District Courts generally receive more tax filings than the Court of Federal Claims. For example, during the years 1975 through 1984, the Tax Court received $95.58 \%$ of tax cases filed, the Court of Federal Claims $0.076 \%$, and the District Courts $3.65 \%$. See Charles E. 
unclear the limits on their power are.

The United States Supreme Court has held that the Tax Court's predecessor court lacked equitable powers. ${ }^{10}$ That could end the inquiry. Yet, the Tax Court increasingly has used equitable doctrines in deciding cases in ways contrary to the result indicated by a straightforward application of applicable statutes. ${ }^{11}$ Public choice theory teaches that judges may seek to maximize their power by expanding the jurisdiction of their courts and through decisions that go beyond the governing statutes. ${ }^{12}$ The Tax Court's application of equity reflects both of these tendencies.

To elucidate the limits Article I of the Constitution places on legislative courts, this article considers the question of the extent, if any, of the equitable powers of the Tax Court under Article I. Part I of the article considers generally the role of Article I courts in the federal system, and the constitutional limits on that role. Next, Part I traces the Tax Court's evolution into an Article I court.

Boynton IV \& Jack Robison, Choosing District Court over Tax Court: Some Case Characteristics, 36 Tax Notes 807, 808 Table 1 (1987). In fiscal year 1999, approximately 20.400 of 20.799 federal tax cases (98.08\%) were filed in Tax Court. See Report to ABA, supra note 2, at 8, 22. In general, the comparison of the number of Tax Court cases to refund court tax cases was starkest during the tax shelter era because of the particularly high volume of Tax Court case filings. See infra note 46.

10. See Commissioner v. Gooch Milling \& Elevator Co., 320 U.S. 418 (1943) (Board of Tax Appeals, predecessor of the Tax Court, had no equity jurisdiction); see also Commissioner v. McCoy, 484 U.S. 3, 7 (1987) ("[T] he Tax Court is a court of limited jurisdiction and lacks general equitable powers."). There is an argument that "general equitable powers" differ from application of equitable principles. For a discussion of the distinction, see infra text accompanying note 131 .

11. See, e.g., Estate of Mueller v. Commissioner, 101 T.C. 551, 553 (1993) (applying equitable recoupment); Orenstein v. Commissioner, 79 T.C. Memo (CCH) 1971 (2000) (same); Alderman v. Commissioner, 55 T.C. Memo (CCH) 86, T.C. Memo (RIA) if 88,049 (1988) (applying equitable estoppel); see also Bachner v. Commissioner, 109 T.C. 125, 131 n.7 (1997) ("In a Tax Court proceeding, either party is free to raise equity-based defenses to the assertions of the other party, and the Court, insofar as it has jurisdiction over the main claim, is free to entertain those defenses.").

The Internal Revenue Service (IRS) has not stemmed the equity tide; in fact, in one recent instance the IRS immediately reversed itself, acquiescing in an apparentreach for equitable power by the Tax Court. See infra notes 272-273 and accompanying text.

12. See Edward L. Rubin, Beyond Public Choice: Comprehensive Rationality in the Writing and Reading of Statutes, 66 N.Y.U. L. Rev. 1, 51 (1991) ("Rather than trying to protect their power, judges might be trying to maximize it, another approach related to the public choice analysis of administrators. If one imagines this as an effort to expand judicial jurisdiction, one is left with effects that are as occasional and as marginal as the power-protection hypothesis. Alternatively, judges could be trying to expand their power through their substantive rulings. Under this theory, judges would ignore statutory language whenever possible or frame rules of construction that permitted them to ignore this language. There is some empirical support for this hypothesis.") (footnote omitted); see also Richard A. Posner, What Do Judges and Justices Maximize? (The Same Thing Everybody Else Does), 3 Sup. Ct. Econ. Rev. 1, 2 (1993); William Landes \& Richard Posner, The Independent Judiciary in an Interest-Group Perspective, 18 J.L. \& Econ., 875, 885-87 (1975). 
Part II considers the meaning and scope of the terms "equity" and "equitable powers," providing both a brief history of the development of equity in England and America, and an analysis of the distinction between "law" and "equity." This part also considers the use of equity in Article I courts. In particular, it considers the Tax Court's use of equity, focusing on the doctrines of equitable recoupment and estoppel, and statutory equitable relief from joint and several tax liability for an "innocent" spouse.

Part III combines the analyses of Article I courts and equity, focusing on the Tax Court. This part considers the argument made by some tax lawyers that because outcomes in the Tax Court should be the same as outcomes in similar cases in the Article III district courts, the Tax Court must have equitable powers. Next, it examines possible sources of equitable power for the Tax Court, including applicable statutes and the possible equity-like ancestry of Tax Court overpayment claims.

The article concludes that Article I courts have limited sources of equitable power, and that even Article I courts granted equitable powers by Congress must be alert to possible derogation of the judicial power of Article III. Given those constraints, the Tax Court's tendency to apply equitable doctrines when necessary to avoid harsh outcomes dictated by statute lacks constitutional authority. For the Tax Court to apply equitable principles as it has been doing, Congress will need to take appropriate action - within constitutional limits - to broaden or redefine the jurisdiction of the court.

\section{THE ROLe AND POWERS OF ARTICle I COURTS}

\section{A. The Constitutional Role of Legislative Courts}

The current federal court system consists of both Article I and Article III courts. Article III of the United States Constitution sets forth the general outline of federal judicial power:

The judicial Power of the United States, shall be vested in one supreme Court, and in such inferior Courts as the Congress may from time to time ordain and establish.... The judicial Power shall extend to all Cases, in Law and Equity, arising under this Constitution, the Laws of the United States, and Treaties made ... under their Authority; [and] . . . to Controversies to which the United States shall be a Party."13 
Courts such as the federal district courts and the Courts of Appeals are established by Congress under that power. ${ }^{14}$ Other courts, including the Tax Court, are created using Congress' power under Article I of the Constitution. ${ }^{15}$ Article I courts are created by Congress under its powers enumerated in, and the "necessary and proper" clause of, Article . $^{15}$ Article I courts differ from Article III courts in that they are not subject to the restrictions of Article III. That is, Article I judges need not have life tenure, ${ }^{16}$ and their pay may be diminished. ${ }^{17}$ Article I courts are also not subject to the "case or controversy" limitation in Article III. ${ }^{18}$ Thus, Article I courts constitutionally may give advisory opinions to Congress. ${ }^{19}$

The well-known constitutional doctrine of "separation of powers" separates and balances the roles of the Article I legislature, Article II executive branch, and Article III judiciary. A branch of government violates separation of powers if it either assumes power of another branch or gives away too much of its own power. ${ }^{20}$ Given the seemingly mandatory language of Article III, ${ }^{21}$

14. U.S. Const. art. III. $\S 1$.

15. See, e.g., Richard B. Saphire \& Michael E. Solimine, Shoring up Article III: Legislative Court Doctrine in the Post CFTC v. Schor Era, 68 B.U. L. Rev. 85, 127 (1988) ("the Court has viewed [the] power [to create non-Article III courts] as premised on Congress's power under Article I's 'necessary and proper clause' power to implement its enumerated powers.") (footnote omitted); Martin H. Redish, Legislative Courts, Administrative Agencies, and the Northern Pipeline Decision, 1983 Duke L.J. 197, 198 ("Congress will usually employ one of its enumerated powers in Article I, in combination with the 'necessary-and-proper' clause of that same Article.").

16. See Erwin Chemerinsky, Federal Jurisdiction 181-82 (Little Brown \& Co. 1989); Resnik, supra note 1, at 912 ("In short, 'the federal courts' include many 'judges' who lack life tenure."). Tax Court judges, for example, serve fifteen-year terms. See IRC § 7443(e).

17. See Chemerinsky, supra note 16, at 181-82; Resnik, supra note 1, at 910-911; cf. Burns, Stix Friedman \& Co., Inc. v. Commissioner, 57 T.C. 392, 395 (1971), ("Did the provisions of the Tax Reform Act of 1969 so change the status and function of the Tax Court that it is now exercising the 'judicial powers' referred to in Article III and must be established as an Article III court with its judges having the tenure and compensation protection provided in section 1 of Article III? We think not.").

18. See Leandra Lederman, Precedent Lost: Why Encourage Settlement, and Why Allow Non-Party Involvement in Settlements?, 75 Notre Dame L. Rev. 221, 248 (1999); U.S. Const. art. III. \$ 2, cl.1.

19. See DonaldD. Haber, The Declaratory Powers of Bankruptcy Courts to Determine the Federal Tax Consequences of Chapter 11 Plans, 3 Am. Bankr. Inst. L. Rev. 407, 426 (1995). Interestingly, the Supreme Court found that the Court of Claims was an Article III Court although it had the power to render advisory opinions. See Glidden v. Zdanok, 370 U.S. 530, 586-87 (1962); (Clark, J., concurring). The Tax Court, however, does not have statutory jurisdiction to give Congress advisory opinions.

20. See Glidden, at 605 .

21. See U.S. Const. art. III. $\S 1$ ("The judicial Power of the United States, shall be vested in one supreme Court, and in such inferior Courts as the Congress may from time to time ordain and establish") (emphasis added). The "inferior Courts" referred to in Article III are Article III courts created by Congress under art. I $\S 8$, cl. 9 (the "inferior tribunals" clause) not Article I "legislative" courts. 
Article I courts are an odd creation. Their very existence appears to be prima facie evidence of an infringement by the legislature on the judicial power expressly granted to Article III courts. Nonetheless, despite the language of Article III, Article I courts are so accepted today that commentators consider "a return to 'Article III literalism' virtually unthinkable."22

The approval of Article I courts by the Supreme Court may be traced back to the 1800s. In 1828, the Supreme Court upheld territorial courts created under Article $\mathrm{I}^{23}$ and, even earlier, in Marbury v. Madison, recognized the right of William Marbury to his commission for a five-year term as a Justice of the Peace in the District of Columbia, thereby apparently allowing the exercise of judicial power without the lifetime tenure required by Article III. ${ }^{24}$ Since then, the Supreme Court has upheld the constitutionality of Article I courts such as the Superior Court and Court of Appeals for District of Columbia; ${ }^{25}$ the predecessor of the current Court of Federal Claims, the Court of Claims; ${ }^{26}$ the now-defunct Court of Customs Appeals; ${ }^{27}$ the territorial courts; ${ }^{28}$ and, by implication, the predecessor to the Tax Court, the Board of Tax Appeals. ${ }^{29}$

Nonetheless, Article I courts have not experienced entirely smooth sailing. ${ }^{30}$ In Northern Pipeline v. Marathon Pipe Line Co.,${ }^{31}$ the Supreme Court

22.M. Isabel Medina, Judicial Review-A Nice Thing? Article III, Separation of Powers and the Illegal Immigration Reform and Immigrant Responsibility Act of 1996, 29 Conn. L. Rev. 1525. 1550 (1997) (footnotes omitted) (quoting Fallon, supra note 3, at 938).

23. See American Ins. Co. v. Canter, 26 U.S. 511 (1828); Fallon, supra note 3, at 916.

24. See Akhil Reed Amar, Marbury, Section 13, and the Original Jurisdiction of the Supreme Court, 56 U. Chi. L. Rev. 443, 451 (1989); Marbury v. Madison, 5 U.S. 137, 162 (1803).

25. See Palmore v. United States, 411 U.S. 389 (1973).

26. See Williams v. United States, 289 U.S. 553 (1933).

27. See Ex Parte Bakelite Corp., 279 U.S. 438 (1929).

28. See American Ins. Co. v. Canter, 26 U.S. 511 (1828).

Historically, Supreme Court case law confined Congress' power to create Article I courts to certain areas. Article I courts that fall in the following four categories have been held constitutionally permissible: “(1) for United States possessions and territories, (2) for military matters, (3) for civil disputes between the United States and private citizens, and (4) for criminal matters or for disputes between private citizens where the legislative court serves as an adjunct to an Article III court that can review the legislative court's decisions." Chemerinsky, supra note 16 , at 184.

29. Phillips v. Commissioner, 283 U.S. 589, 599-601 (1931) (review by Board of Tax Appeals is constitutionally adequate); cf. Freytag v. Commissioner, 501 U.S 868, 873 (1991) (upholding constitutionality of Tax Court's use of special trial judges appointed by the Chief Judge of the Tax Court). Lower courts have held the Tax Court Constitutional. See, e.g., Shenker v. Commissioner, 804 F.2d 109, 114 n.6 (8th Cir. 1986), cert. denied, 481 U.S. 1068 (1987); Knoblauch v. Commissioner, 749 F.2d 200, 202 (5th Cir. 1984), cert. denied, 474 U.S. 830 (1985); Sparrow v. Commissioner, 748 F.2d 914, 915 (4th Cir. 1984); Redhouse v. Commissioner, 728 F.2d 1249, 1253 n.2 (9th Cir. 1984), cert. denied, 469 U.S. 1034 (1984).

30. See Deborah A. Geier, The Tax Court, Article III, and the Proposal Advanced by the Federal Courts Study Committee: A Study in Applied Constitutional Theory, 76 Comell L. Rev. 985, 1002 (1991) (discussing Northern Pipeline decision).

31.458 U.S. 50 (1982). 
held unconstitutional a prior incarnation of the bankruptcy courts. ${ }^{32}$ After Northern Pipeline, in determining the constitutionality of an Article I court, the Court has balanced the desirability of an Article I court against the degree of encroachment on the Article III judiciary. "Among the factors upon which we have focused are ... the extent to which the non-Article III forum exercises the range of jurisdiction and powers normally vested only in Article III courts, the origins and importance of the right to be adjudicated, and the concerns that drove Congress to depart from the requirements of Article III. ${ }^{.34}$

\section{B. The Tax Court as an Article I Court}

The Tax Court became a legislative court under Article I of the Constitution ${ }^{35}$ as part of the Tax Reform Act of $1969 .{ }^{36}$ Prior to 1969 , the Tax Court was an executive agency, originally named the Board of Tax Appeals (Board). The Board was created in $1924 .{ }^{37}$ Initially, there was no appeal from a Board of Tax Appeals decision. However, the losing party could file a lawsuit "where the findings of the Board would be taken as prima facie evidence of the facts." 38 In 1926, Congress made decisions from the Board directly appealable to the Circuit Courts of Appeals. ${ }^{39}$

In 1942, Congress changed the Board's name to the Tax Court of the United States, ${ }^{40}$ but it was not until 1969 that the Tax Court officially became a court. ${ }^{41}$ The process by which the Tax Court became an Article I court was almost an accident of the periodic struggle of various parties between 1943 and 1969 to obtain judicial status, and particularly Article III status, for the Board of Tax Appeals. ${ }^{42}$

As chances for achieving article III status for the Tax Court became increasingly bleak, Congressman Mills submitted an alternative bill in 1969 providing for legislative court status

32. See Northern Pipeline, 458 U.S. 50 (1982).

33. See Commodity Futures Trading Commission v. Schor, 478 U.S. 833 (1986); Thomas v. Union Carbide Agricultural Products Co., 473 U.S. 568 (1985); see also Susan BlockLieb, The Costs of a Non-Article III Bankruptcy Court System, 72 Am. Bankr. L.J. 529, 537-38 (1998) (citing Chemerinsky, supra note 16 at $\$ 4.5 .4$ (1994)).

34. Schor, 478 U.S. at 851 (citations omitted).

35. See IRC $\$ 7441 ;$ Freytag, 501 U.S. at 887 (In 1969, Congress expressly made the Tax Court an Article I court rather than an executive agency).

36. Pub. L. No. 91-172, § 951, 83 Stat. 487, 730.

37. Revenue Act of 1924, ch. 234, § 900, 43 Stat. 253, 336.

337).

38. Geier, supra note 30 , at 990 (citing Revenue Act of 1924 , ch. $234, \S 900$ (g), 43 Stat.

39. Revenue Act of 1926, ch. 27, §§ 1001(a), 1002, 44 Stat. 9, 109-10.

40. Revenue Act of 1942, ch. 619, § 504(a), 56 Stat. 798.

41. See supra note 36 and accompanying text.

42. See Geier, supra note 30, at 991-993. 
under article I. No public hearings were held on the subject, and the provisions of the bill "were quietly inserted into the Tax Reform Act of 1969 by the Senate Finance Committee in executive session," becoming law on December 30, 1969. ${ }^{43}$

\section{The Tax Court has remained an Article I court ever since.}

The Tax Court's primary function since its inception as the Board of Tax Appeals has been to provide taxpayers an opportunity to litigate tax disputes with the IRS without paying the disputed amount first. ${ }^{44}$ Although the Tax Court has jurisdiction over a multitude of types of claims, ${ }^{45}$ the bulk of its

43. Id. at 993 (footnote omitted) (quoting Harold Dubroff, The United States Tax Court: An Historical Analysis 214 (Commerce Clearing House, Inc. 1979)).

44. See Appeal of Everett Knitting Works, 1 B.T.A. 5. 6 (1924) ("The Board was created to give the taxpayer a chance to have an open and neutral consideration of his liability for a deficiency before he is required to pay. The harsh rule of payment first and litigation afterwards was sought to be mitigated."); Hoffman \& Cihlar, supra note 8, at 869 ("The purpose of the Board [of Tax Appeals] was to ensure that in most cases a taxpayer could obtain an independent review of a tax deficiency determination before the tax was assessed."): Leo P. Martinez, The Summons Power and Tax Court Discovery: A Different Perspective, 13 Va. Tax Rev. 731, 742 (1994) ("The United States Tax Court was established to provide taxpayers with a forum for informal and inexpensive adjudication of purported tax payment deficiencies."); cf. Flora v. United States, 357 U.S. 63, 75 (1958) ("It is suggested that a part-payment remedy is necessary for the benefit of a taxpayer too poor to pay the full amount of the tax. Such an individual is free to litigate in the Tax Court without any advance payment.").

45. Tax Court jurisdiction extends to (1) tax deficiency cases; (2) overpayment claims incidental to its deficiency jurisdiction; (3) certain actions for attorney's fees; (4) declaratory judgment actions in specific types of cases; (5) proceedings for determination of employment status; (6) certain actions for disclosure of IRS written determinations; (7) innocent spouse claims; (8) collection due process claims; (9) adjustments of partnership items; and (10) IRS denial of requests for abatement of interest. See IRC $\$ \S 6213$ (a) ("Within 90 days, or 150 days if the notice is addressed to a person outside the United States, after the notice of deficiency authorized in section 6212 is mailed (not counting Saturday, Sunday, or a legal holiday in the District of Columbia as the last day), the taxpayer may file a petition with the Tax Court for a redetermination of the deficiency."), 6214(a) ("Except as provided by section 7463, the Tax Court shall have jurisdiction to redetermine the correct amount of the deficiency even if the amount so redetermined is greater than the amount of the deficiency, notice of which has been mailed to the taxpayer, and to determine whether any additional amount, or any addition to the tax should be assessed, if claim therefor is asserted by the Secretary at or before the hearing or a rehearing."), 6512(b)(1) ("Except as provided by paragraph (3) and by section 7463, if the Tax Court finds that there is no deficiency and further finds that the taxpayer has made an overpayment of ... tax ... in respect of which the Secretary determined the deficiency, or finds that there is a deficiency but that the taxpayer has made an overpayment of such tax, the Tax Court shall have jurisdiction to determine the amount of such overpayment, and such amount shall, when the decision of the Tax Court has become final, be credited or refunded to the taxpayer."), 7430 (awards of administrative and litigation costs and fees), 7428 (declaratory judgments relating to status and classification of organizations under $\$ 501$ (c)(3), etc.), 7476 (declaratory judgments relating to qualification of certain retirement plans), 7477 (declaratory judgments relating to value of certain gifts, 7478 (declaratory judgments relating to status of certain governmental obligations, 7479 (declaratory judgments relating to eligibility of estate with respect to installment payments under $\S 6166$ ), 
caseload consists of tax deficiency cases in which the IRS has mailed the taxpayer a notice of deficiency (asserting an understatement of taxes) and the taxpayer has filed a timely responsive petition. ${ }^{46}$ For the Tax Court to have jurisdiction over the subject matter of a deficiency case, the IRS must have mailed the taxpayer a notice of deficiency for a particular tax period, ${ }^{47}$ and the taxpayer must have filed a timely responsive petition. ${ }^{48}$ In general, the court's jurisdiction extends only to the tax year(s) that are the subject of the notice of deficiency and the petition. ${ }^{49}$ The Tax Court also has pendent jurisdiction over the taxpayer's overpayment claims with respect to those tax years. ${ }^{50}$ These deficiency cases could, alternatively, and at the option of the taxpayer, be litigated in the Court of Federal Claims or the District Courts (the so-called "refund fora"). ${ }^{51}$ However, the refund fora, unlike the Tax Court, require payment of the full amount in dispute before litigating. ${ }^{52}$

7436 (proceedings for determination of employment status), 6110(f) (resolution of disputes relating to disclosure), 6015(e) (innocent spouse claims), 6330(d)(1)(A) (hearing before levy on taxpayer property), 6226 (judicial review of final partnership administrative adjustments), and 6404(i) (review of IRS denial of taxpayer request for abatement of interest).

46. For example, as of September 30,2000, the Tax Court had a docket of 16,609 cases in which a total over $\$ 28$ billion were at stake, and only 37 declaratory judgment cases. See Report to ABA, supra note 2, at 4.

The Tax Court's overall docket has shrunk as tax shelter cases have been resolved. In $1987,42,623$ cases were filed in Tax Court, while only 1,100 refund cases were filed in the District Courts and Court of Federal Claims combined. See United States Tax Court, 1994 Fiscal Year Statistical Information (1994); William F. Nelson \& James J. Keightley, Managing the Tax Court Inventory, 7 Va. Tax Rev. 451, 453 (1988). After a slight increase from 1985 to 1986 in the number of Tax Court cases filed (48,398 in fiscal year 1986), the number of cases filed hovered around 30,000 from 1988 through 1993, dropping to 23,524 in fiscal year 1994. See United States Tax Court, 1994 Fiscal Year Statistical Information (1994). The numbers continue to drop. In 1998, approximately 21,400 cases were filed, and in 1999, approximately 13,700 were filed. See Report to $A B A$, supra note 2 , at 8 .

47. See IRC \& 6212.

48. See IRC $\$ 6213$.

49. See IRC $\$ 6214$ (b) ("The Tax Court in redetermining a deficiency of income tax for any taxable year or of gift tax for any calendar year or calendar quarter shall consider such facts with relation to the taxes for other years or calendar quarters as may be necessary correctly to redetermine the amount of such deficiency, but in so doing shall have no jurisdiction to determine whether or not the tax for any other year or calendar quarter has been overpaid or underpaid."). The Tax Court's application of equitable recoupment in spite of this section is discussed infra at Part $\mathrm{W}(\mathrm{B})(2)(\mathrm{a})$.

50. See IRC \& 6512(b).

51. A taxpayer who has received a notice of deficiency faces a choice of fora. He may petition the Tax Court, generally within 90 days of the date on the notice. See IRC $\S 6213$. He also has the option of paying the deficiency and following the refund procedures that will afford jurisdiction in the refund courts. Leandra Lederman \& Stephen W. Mazza, Tax Controversies: Practice and Procedure 9 (MatthewBender \& Co., Inc. 2000). The refund procedures require that the taxpayer pay the tax and then claim a refund from the IRS. See IRC $\S 6511$; Lederman \& Mazza, supra, at 10-11.

52. See Flora v. United States, 362 U.S. 145, 189 (1960). 
The Tax Court undoubtedly is constitutional under the Northern Pipeline test. ${ }^{53}$ It does not exercise all of the judicial powers of the federal district courts, such as conducting jury trials and issuing writs of habeas corpus. ${ }^{54}$ In fact, the Tax Court exercises a narrower, more specialized jurisdiction ${ }^{55}$ that is permitted because Congress has waived the federal government's sovereign immunity with respect to the type of claims the court adjudicates.

Nonetheless, the Tax Court, like all Article I courts, is subject to limits to avoid unconstitutional usurpation of Article III powers. The Supreme Court stated in Commodity Futures Trading Commission v. Schor ${ }^{56}$ that in ruling on the constitutionality of an Article I court, one of the factors it considers is "the extent to which the non-Article III forum exercises the range of jurisdiction and powers normally vested only in Article III courts ...." Although this is only one factor, and although the Court would be unlikely to find the Tax Court unconstitutional, it could find its use of equity unconstitutional.

\section{The Powers of Article I Courts}

Supreme Court jurisprudence on Article I courts reflects the Court's struggle to distinguish Article I from Article III courts. In one case, the Court stated, "we think it proper to state that we do not consider congress can ... withdraw from judicial cognizance any matter which, from its nature, is the subject of a suit at the common law, or in equity, or admiralty.... At the same time there are matters, involving public rights, which may be presented in such form that the judicial power is capable of acting on them, and which are susceptible of judicial determination, but which congress may or may not bring within the cognizance of the courts of the United States, as it may deem proper." An Another case distinguished "public rights" suits, which may be decided by Article I courts, from those that are "inherently judicial." 59 In

53. Cf. Freytag v. Commissioner, 501 U.S. at 873 (upholding constitutionality of Tax Court's use of special trial judges appointed by the Chief Judge of the Tax Court); Shenker v. Commissioner, 804 F.2d 109, 114 n.6 (8th Cir. 1986) (upholding constitutionality of Tax Court), cert. denied, 481 U.S. 1068 (1987).

54. See Schor, 478 U.S., at 852-53 (1986) (finding that Commodity Futures Trading Commission (CFTC) does not exercise all powers of district courts, and citing as examples CFTC's inability to conduct jury trials or issue writs of habeas corpus).

55. See id. at 852 (approving the CFTC as focusing on only a "particularized area of law") (citing Northern Pipeline, 458 U.S. at 85); Hoffman \& Cihlar, supra note 8, at 869 ("The United States Tax Court is the paradigm of an Article I court and the quintessential specialty court.").

56. 478 U.S. 833 (1986).

57. Id. at 851 (citations omitted).

58. Den, ex dem. Murray v. Hoboken Land and Improvement Co., 59 U.S. 272, 284 (1855).

59. See Northern Pipeline Constr. Co. v. Marathon Pipe Line Co., 458 U.S. 50, 68 
general, public rights suits involve the government as a party. ${ }^{60}$ The case law also indicates that because Article I courts are legislative courts subject to Congress' statutory control, they are more limited in their powers than Article III courts. ${ }^{61}$

There seems to be little dispute that Article I courts can decide constitutional questions, even without express statutory authority. ${ }^{62}$ Professor Dubroff has pointed out that the Tax Court cannot determine the correctness of the IRS's assertion of a deficiency "by simply examining the tax statutes in a vacuum." 63 In effect, this allows the legislative branch to decide the constitutionality of its own statutes. This potentially broad power is constrained by the accepted practice of resolving issues, if at all possible, on nonconstitutional grounds. ${ }^{64}$

Although it might seem that the power to decide constitutional questions would indicate the power to use equity (as a sort of lesser included power), in fact, these two powers are not related in this manner. The Board of Tax Appeals, an executive agency, considered constitutional questions when it faced them. ${ }^{65}$ By contrast, in Commissioner v. Gooch Milling \& Elevator Co. ${ }^{66}$ the Supreme Court held that the Board of Tax Appeals had no equity jurisdiction. The Court reasoned that the jurisdiction of the Board was expressly defined in the Code, and Congress had not granted the Board equity

(1982); see also William M. Millard, Note, Eroding the Separation of Powers: Congressional Encroachment on Federal Judicial Power: CFTC v. Schor, 53 Brooklyn L. Rev. 669 (1987).

60. See Northern Pipeline Constr. Co., 458 U.S., at 69 (1982) (citing Ex parte Bakelite Corp., 279 U.S. 438, 451 (1929)); Ellen E. Sward \& Rodney F. Page, The Federal Courts Improvement Act: A Practitioner's Perspective, 33 Am. U. L. Rev. 385, 409 (1984).

61. See, e.g., Commissioner v. McCoy, 484 U.S. 3, 7 (1987) (per curiam) ("The Tax Court is a court of limited jurisdiction and lacks general equitable powers."); Chavez v. United States, $18 \mathrm{Cl}$. Ct. 540, 547 (1989) ("[T] $]$ his court is an Article One court with very specific jurisdiction granted by the congress. This legislative grant of equitable jurisdiction is to be strictly construed."); In re Hessinger \& Assocs., 192 B.R. 211, 215 (Bankr. N.D. Ca. 1996) ("[B]ecause the bankruptcy courts are creatures of Article I, they have no 'inherent' powers and their jurisdiction is limited to that expressly granted by Congress.").

62. See Harold Dubroff, The United States Tax Court: An Historical Analysis 214,47980 (Commerce Clearing House, Inc. 1979) (discussing Tax Court's power to decide constitutional questions); see also Boyce v. Commissioner, 97-2 U.S. Tax Cas. (CCH) ๆ 50,681 (9th Cir. 1997) ("[T]he Tax Court has jurisdiction over constitutional questions even though it is not an Article III court."); Rager v. Commissioner, 775 F.2d 1081, 1083 (9th Cir. 1985) ("Taxpayers argue that because the Tax Court is not an Article III court, it cannot have jurisdiction over constitutional questions. Taxpayers' argument is frivolous; we have often upheld Tax Court decisions which were based on a constitutional inquiry.").

63. Dubroff, supra note 62 , at 482 .

64. See Brian C. Murchison, Interpretation and Independence: How Judges Use the Avoidance Canon in Separation of Powers Cases, 30 Ga. L. Rev. 85 (1995).

65. See Dubroff, supra note 62, at 480 (describing the Board of Tax Appeals' consideration of constitutional questions, beginning as early as 1926).

66. 320 U.S. 418 (1943). 
jurisdiction. ${ }^{67}$ In effect, the power to decide the constitutionality of statutes has been accepted as necessary to making decisions regarding those statutes. ${ }^{68} \mathrm{By}$ contrast, a court need not have the power to do equity in order to make decisions about the application of statutes.

Eskridge and Frickey have cogently argued that the Supreme Court draws on canons of statutory interpretation to advance constitutional values such as separation of powers. ${ }^{69}$ The Court may use a variety of canons to avoid a separation of powers violation, including avoidance of unnecessary constitutional questions, ${ }^{70}$ a presumption against derogation of the judiciary's inherent powers, ${ }^{71}$ a presumption against derogation of the President's traditional executive powers, ${ }^{72}$ and the nondelegation doctrine that applies to the legislature. ${ }^{73}$

The presumption against derogation of the inherent power of the judiciary precludes another branch, such as the legislature, from infringing upon the "judicial Power" granted to courts in Article III. For example, in Link v. Wabash R. Co. ${ }^{74}$ the Court held that Federal Rule of Civil Procedure 41(b), which allows a defendant to move for involuntary dismissal of an action or claim, ${ }^{75}$ did not limit a court's power to dismiss for failure to prosecute to instances where a defendant moves for dismissal, but rather allowed a court to dismiss the case sua sponte. Similarly, in Roadway Express, Inc. v. Piper, ${ }^{76}$ the Court held that the courts have "inherent power" to discipline litigants, including the imposition of attorney's fees, regardless of the particular terms of statutes that provide for recovery of costs. ${ }^{77}$

The essential attributes of the "judicial Power" referenced in Article III arguably consist of jurisdiction in cases at common law, in equity, and in admiralty. Certainly the "inherent power" of the judicial branch includes the power to do equity. ${ }^{78}$ Use of that power by another branch of government

67. See id. at 420.

68. See supra note 65 and accompanying text.

69. See William N. Eskridge. Jr. \& Philip P. Frickey, Quasi-Constitutional Law: Clear Statement Rules as Constitutional Lawmaking, 45 Vand. L. Rev. 593 (1992).

70. See Brian C. Murchison, Interpretation and Independence: How Judges Use the Avoidance Canon in Separation of Powers Cases, 30 Ga. L. Rev. 85 (1995).

71. Eskridge \& Frickey, supra note 69, at 605.

72. Id. at 606.

73. Cass R. Sunstein, Nondelegation Canons, 67 U. Chi. L. Rev. 315 (2000); Eskridge \& Frickey, supra note 69, at 606.

74. 370 U.S. 626,632 (1962).

75. Fed. R. Civ. P. 41(b).

76. 447 U.S. 752. 764-67 (1980).

77. This example appears in Eskridge \& Frickey, supra note 69, at 605.

78. See, e.g., Porter v. Warner Holding Co., 328 U.S. 395, 397 (1946); Brotherhood of Locomotive Engineers v. Baltimore \& O. R. Co., 310 F.2d 513, 516 (7th Cir. 1962). See also Bell v. Hood, 327 U.S. 678, 684 (1946) (inherent power of a federal court to enjoin threatened or actual violation of constitutional rights); Robert Lincoln, Executive Decisionmaking by Local Legislatures in Florida: Justice, Judicial Review and the Need for Legislative Reform, 25 Stetson 
therefore may infringe upon the power of the judicial branch. As with any separation of powers issue, assertion by the legislative branch of equitable powers raises the question of what the limits are before the assertion is an unconstitutional derogation of the powers of the judiciary.

The use of canons of construction to advance constitutional values would suggest that the jurisdiction of Article I courts should be narrowly construed. Narrow construction of the jurisdiction of Article I courts is consistent with avoidance of constitutional questions in that it avoids separation of powers problems. Arguably, Article I courts constitutionally may consider only statutory causes of action. This would suggest that, in the absence of statutory authorization of equitable powers, an Article I court does not have such powers.

Of course, sometimes statutes expressly authorize equitable considerations or equitable causes of action, even in Article I courts like the Tax Court. For example, the Tax Court has longstanding declaratory judgment jurisdiction, and must weigh the equities in awarding an innocent spouse relief from joint and several liability. ${ }^{79}$ Are those unconstitutional derogations of the judicial power of Article III courts? The statutory grant of equitable power is necessary but not sufficient under the constitution. The statute could be unconstitutional on its face, or unconstitutional as applied in a particular case.

\section{THE ORIGINS OF EQUITY AND ITS USE IN ARTICLE I COURTS}

\section{A. A History of Equity}

"In a broad jurisprudential sense, equity means the power to do justice in a particular case by exercising discretion to mitigate the rigidity of strict legal rules." ${ }^{80}$ However, the modern use of the term "equity" with respect to courts' jurisdiction and power reflects the historical development, first in England and then in America, of two distinct judicial systems. ${ }^{81} \mathrm{~A}$ brief

L. Rev. 627, 655 (1996) ("[F]undamental judicial powers generally involve issues for which the right to a jury trial is protected, equitable powers, and the inherent judicial power to control proceedings.").

79. See IRC \& 6015(b), (e).

80. Kevin C. Kennedy, Equitable Remedies and Principled Discretion: The Michigan Experience, 74 U. Det. Mercy L. Rev. 609, 610 (1997) ("All writers on the subject of equity, regardless of their philosophical persuasion, agree that the terms 'equity' and 'equitable' are difficult to define.").

81. Prior to the distillation in two courts, the courts of law and the courts of equity, there were multiple, competing venues. The common law courts were the Exchequer, Common Pleas, and King's Bench. See Daniel J. Meador, Transformation of the American Judiciary, 46 Ala. L. Rev. 763, 770 (1995). The ecclesiastic courts applied the canon law of the Catholic Church. Jack Moser, The Secularization of Equity: Ancient Religious Origins, Feudal Christian Influences, and Medieval Authoritarian Impacts on The Evolution of Legal Equitable Remedies, 26 Cap. U. L. Rev. 483, 517 (1997). The English Court of Chancery drew upon the practices of 
overview of the equity system is therefore in order.

1. The Development of Equity in England.-Historically, litigation in England took place in a two-court system: "common law" or "law" courts, and "Chancery" or "equity" courts. ${ }^{82}$

By the early sixteenth century it was apparent that the common law system was accompanied by a substantially different one called equity. Equity was administered by the Chancellor, as distinguished from the three central common law courts with their common law judges... . The main staples of Chancery jurisdiction became the broader and deeper reality behind appearances, and the subtleties forbidden by the formalized writ, such as fraud, mistake, and fiduciary relationships. ${ }^{83}$

Because common law courts awarded only after-the-fact money damages, which did not provide appropriate relief in all cases, the court of Chancery made available both preventive injunctive relief and nonemontary relief such as specific performance. ${ }^{84}$ "That this court was attempting to do 'equity,' that is to accomplish justice, gave rise to the term 'equity' as the designation for the system of jurisprudence involved, and the court that dispensed it as a court of equity." 85

Equity is probably noted most for its remedies. Injunctions and specific performance are the classic equitable remedies. ${ }^{86}$ Other equitable remedies include rescission and reformation of contracts, and imposition of constructive trusts. $^{87}$ In fact, equity consisted of several additional elements that distinguished it from law: its pleading practice, ${ }^{88}$ including its causes of action ${ }^{89}$

the ecclesiastical courts. See Moser, supra, at 485-486; Timothy S. Haskett, The Medieval English Court of Chancery, 14 Law \& Hist. Rev. 245, 256-257 (1996).

82. Stephen N. Subrin, How Equity Conquered Common Law: The Federal Rules of Civil Procedure in Historical Perspective, 135 U. Pa. L. Rev.909,914 (1987). "Lawyers well into the nineteenth century on both sides of the Atlantic viewed the 'common law' procedural system as comprising the writ or form of action, the jury, and the technical pleading requirements that attempted to reduce cases to a single issue." Id. at 917. Previously, there were multiple, competing courts. See supra note 81 .

83. Id. at 918 (footnotes omitted).

84. See Kennedy, supra note 80 , at 612 .

85. Id.

86. See Kennedy, supra note 80, at 627 ("Equitable remedies can be divided into two kinds: coercive and restitutionary. Coercive, or injunctive, remedies are the most common.").

87. See The Honorable Marcia S. Krieger, "The Bankruptcy Court Is a Court of Equity": What Does That Mean?, 50 S.C. L. Rev. 275, 281 (1999).

88. See Kroger, supra note 7, at 1433.

89. Moser, supra note 81 , at 484 (footnote omitted). Historically, certain causes of action, such as accountings and novel disseisin, were cognizable only in equity courts. See, e.g., Natalie A. DeJarlais, Note, The Consumer Trust Fund: A Cy Pres Solution to Undistributed 
and defenses, ${ }^{90}$ and its system of discovery.$^{91}$ Furthermore, actions in equity also generally were not triable by jury, ${ }^{92}$ and "certain forms of property, such as mortgages and trusts, were recognized only in equity courts." $" 93$

Equity developed maxims that limited its application to those cases in which it was thought justice could be done through equity. Those maxims include, "equity does not suffer wrong to be without a remedy" seeks equity must do equity." 95 In addition, equitable relief was available only in equity courts, ${ }^{96}$ and only when there was no adequate remedy at law. ${ }^{97}$ Furthermore, equitable defenses were appropriately raised in response to equitable claims, not claims at law. ${ }^{98}$ Equitable defenses include laches, equitable recoupment, and equitable estoppel. Laches is an equitable defense that refers to the staleness of a claim, ${ }^{99}$ serving a role similar to that of a statute of limitations, which generally did not exist in equity. ${ }^{100}$ For example, in tax

Funds in Consumer Class Actions, 38 Hastings L.J. 729, 732 (1987)("The class action originated in the English courts of chancery with the 'bill of peace.' A creature of equity, the bill of peace allowed a representative of a group of similarly injured persons to bring suit on behalf of absent class members as well as herself."). See also Subrin, supra note 82, at 915 ("The writ of novel disseisin ... was designed to provide for the rapid ejection of one who was wrongfully on the plaintiff's land.").

90. Equitable defenses include laches, seeKennedy, supra note 80, at 622 ("Along with the unclean hands doctrine ... laches is the chief defense to equitable claims brought by a plaintiff who has unreasonably delayed his claim."); unclean hands, George Keeton, An Introduction to Equity 112 (6th ed. 1965) ("He who comes into equity must come with clean hands."); equitable estoppel, see John M. Maguire \& Philip Zimet, Hobson's Choice and Similar Practices in Federal Taxation, 48 Harv. L. Rev. 1281, 1321 (1935); and equitable recoupment, see id.

91. See Kroger, supra note 7, at 1433.

92. See Subrin, supra note 82 , at 920.

93. See Kroger, supra note 7, at 1433.

94. Keeton, supra note 90 , at 89.

95. Id. at 87-117. "This maxim . . . is designed to prevent the unjust enrichment of the plaintiff at the expense of the defendant ...." Kennedy, supra note 80, at 618 .

96. Ellen E. Sward, Legislative Courts, Article III, and the Seventh Amendment, 77 N.C. L. Rev. 1037, 1041 n.15 (1999) ("Courts of law, whose jurisdiction was limited to common law writs, could never hear and decide equitable matters.") (citing S.F.C. Milsom, Historical Foundations of the Common Law 33-36 (2d ed. 1981)).

97. Krieger, supra note 87 , at 279 . This is no longer true in practice. See Douglas Laycock, The Death of the Irreparable Injury Rule, 103 Harv. L. Rev. 687 (1990).

98. See, e.g., County of Oneida v. Oneida Indian Nation, 470 U.S. 226, 244-45 n.16 (1985) ("[A]pplication of the equitable defense of laches in an action at law would be novel indeed."); 1 Dan B. Dobbs, Law of Remedies 2.4(2), at 94 (2d ed. 1993) ("Discretion to deny legal relief would mean that the judge might refuse to permit recovery of personal injury damages to a pedestrian struck down in a crosswalk on the ground that she was on her way to an illicit rendezvous and would not have been injured had she stayed home with her family."); Martin Kasten, Summons at 1600: Clinton v. Jones 'Impact on the American Presidency, 51 Ark. L. Rev. 551,568 (1998) ("Equitable defenses, such as laches, are not available in a case at law.").

99. See Southern Pac. Transp. Co. v. Commissioner, 75 T.C. 497, 840 (1980).

100. See Ashraf Ray Ibrahim, Note, The Doctrine of Laches in International Law, 83

Va. L. Rev. 647, 647 (1997) ("Unlike statutes of limitations, which are legislatively created and 
cases, a taxpayer might assert the defense when the IRS took unusually long in pursuing the case. ${ }^{101}$

2. Equity in the United States.-The American colonies generally distinguished between law and equity ${ }^{102}$ In the United States, the same court often sat in both law and equity, even before the merger of law and equity in $1938 .{ }^{103}$ When a federal court sat in law, juries were used, and in common law actions, federal courts applied state law. ${ }^{104}$ When a federal court sat in equity, a judge decided the case, applying the precedents of the English Chancery court, except as modified by any equity rules promulgated by the Supreme Court. ${ }^{105}$

The language of Article III of the Constitution reflects the then-existing separation of law and equity, stating, in part, "The judicial Power shall extend to all Cases, in Law and Equity, arising under this Constitution . . . ."106

When the framers of the Constitution began to design a system of national courts, they naturally used the English model. The federal courts were to be units of government that exercised "judicial Power," one of the component parts of sovereign authority. They could exercise that power in common law, equity, and admiralty/maritime. ... Although generally deferring to common law's interpretation of substantive rights, federal equity would, like its English predecessor, provide relief from the rigidity of common law by exercising discretion in procedure and remedies. ${ }^{107}$

The Judiciary Act of 1789 granted the federal circuit courts jurisdiction over "suits of a civil nature at common law or in equity" between citizens of different states ${ }^{108}$ but denied equity jurisdiction where there was a complete and adequate remedy at law. ${ }^{109}$ At the time the Judiciary Act was enacted, there was

mechanically applied in courts of law, the doctrine of laches developed as an affirmative defense in courts of equity - historically outside the statute of limitations' purview.").

101. See, e.g., Mecom v. Commissioner, 101 T.C. 374, 391 (1993); Tregre v. Commissioner, 71 T.C. Memo (CCH) 3,098, T.C. Memo (RIA) ๆ 96,243 (1996).

102. Kroger, supra note 7, at 1438. ("By the time of the Constitutional Convention in 1787 , all thirteen states had, at one time or another, granted their courts or governors equity powers.") Id.

103. See Krieger, supra note 87, at 280.

104. Id.

105. Id.

106. U.S. Const. art. III. $\S 2$, cl. 1 (emphasis added).

107. John T. Cross, The Erie Doctrine in Equity, 60 La. L. Rev. 173, 210-11 (1999).

108. 1 Stat. 78 (1789) (quoted in Naomi R. Cahn, Family Law, Federalism, and the Federal Courts, 79 lowa L. Rev. 1073, 1087-88 (1994)).

109. 1 Stat. 73, 82 (1789) (quoted in Baker v. Biddle, 2 F. Cas. 439, 443 (E.D. Pa. 
substantial disagreement as to whether equity focused on judicial discretion without reference to precedence (the traditional view) or instead was subject to specific procedures and stare decisis (the view of reformers). ${ }^{110}$ It was not until after the year 1800 that the Supreme Court, under Chief Justice Marshall, began to depart from the traditional view of equity. ${ }^{11}$

Over time, the Supreme Court began to "blur the lines between law and equity" by importing various legal doctrines, such as stare decisis, into equity. ${ }^{112}$ In 1938 , law and equity were merged in the federal courts through the adoption of the Federal Rules of Civil Procedure. ${ }^{113}$ Generally speaking, as a result of the merger, "in civil matters before the district court ... the distinction between law and equity is now limited to the type of remedy imposed and the parties' right to a jury trial." "114 In addition, the use of equitable defenses is no longer limited to equitable claims. ${ }^{115}$

\section{B. Equity in Article I Courts}

1. In General.-Article I courts are a heterogeneous group. ${ }^{116}$ The bankruptcy courts are commonly termed "courts of equity,"117 although the appellation is misleading. ${ }^{118}$ Congress has expressly granted the Court of Federal Claims certain equitable powers, ${ }^{119}$ and the Tax Court, though lacking at least "general equity jurisdiction," routinely applies equitable principles. Yet, despite their heterogeneity, all Article I courts are creatures of statute.

1831)). This provision "prevent[ed] encroachment upon the common-law right to jury trial inasmuch as the Seventh Amendment had not been adopted at that time," 2 J. Moore, Moore's Federal Practice [ 2.05[1] (2d ed. 1989). This is not surprising because the Seventh Amendment was under consideration by Congress at the time the Judiciary Act passed. Charles Warren, New Light on the History of the Federal Judiciary Act of 1789, 37 Harv. L. Rev. 49, 54 (1923).

110. Kroger, supra note 7, at 1433.

111. Id. at 1446.

112. Kroger, supra note 7, at $1452-1453$.

113. See Ross v. Bernhard, 396 U.S. 531, 539 (1970); Fed. R. Civ. P. 2.

114. Krieger, supra note 87, at 281.

115. See Edward Yorio, A Defense of Equitable Defenses, 51 Ohio St. L.J. 1201, 1205

(1990).

116. Such diverse courts as the Territorial Courts, Military Courts Martial, and the courts for the District of Columbia are all Article I courts. See Ron Weiss, Contempt Power of the Bankruptcy Court, 6 Bank. Dev. J. 205, 239 (1989).

117. See Krieger, supra note 87, at 276 n.1 ("In the author's experience, the frequency of reference to the bankruptcy court as a court of equity is second only to introductions, 'May it please the Court' or 'Good morning (afternoon), Your Honor."').

118. See id. at 292 ("neither bankruptcy law nor bankruptcy courts can claim roots in English courts of equity. Bankruptcy remedies and insolvency rights have always been a product of legislative enactment rather than case-by-case determination in common law or equity courts."); id. at 309 ("bankruptcy courts apply a statutory scheme rather than equitable maxims"). In the United States, bankruptcy is a statutory creation. Bankruptcy courts are courts of "equity" in the fairness sense, rather than in the chancery sense.

119. See infra note 122 and accompanying text; see also Ct. Fed. Cl. 2, 8(e)(2). 
Article III courts have equitable power because it is specifically authorized by Article III itself and granted to these courts by Congress. ${ }^{120}$ Article I does not contain similar language. ${ }^{121}$ Simply being a "court" should not confer equitable power because, constitutionally, there is a difference between constitutional courts that exercise power granted by Article III of the Constitution and legislative courts that may only exercise power expressly conferred by Congress.

Nonetheless, Congress has authorized certain Article I courts to apply equitable principles in certain situations. For example, since 1982, the Court of Federal Claims, an Article I court, has had the power to grant equitable relief in contract actions. ${ }^{122}$ Similarly, the Tax Court has declaratory judgment power in a narrow set of cases. ${ }^{123}$ However, power to grant an equitable remedy, such as an injunction or a declaratory judgment, is still circumscribed by statute.

In general, any equitable power an Article I court exercises finds its source in a statute. The statute defining a court's jurisdiction may specifically authorize the application of equitable relief as is true for the Court of Federal Claims. ${ }^{124}$ Specific statutory provisions that the court is charged with applying may also authorize the use of equity. For example, certain Internal Revenue Code provisions expressly bring equitable principles into the analysis. ${ }^{125}$

In addition to true equitable power, Article I courts may use equitable considerations where that is provided by statute. In such instances, the use of the term "equity" may be a definitional shorthand rather than a true grant of equitable power. In other words, Congress may use the terms "equity" or "equitable" to refer to the types of fairness considerations that are part of the jurisprudence of equity, without actually conferring equitable powers by doing so. For example, as discussed below, ${ }^{126}$ general innocent spouse relief ${ }^{127}$

120. See U.S. Const. art. III. $\S 2$, cl. 1("The judicial Power shall extend to all Cases, in Law and Equity, arising under this Constitution ....").

121. See Cross, supra note 107, at 201 ("Congress cannot delegate authority it does not have. None of Congress's enumerated powers, even when augmented by the Necessary and Proper Clause, are broad enough to cover the entire set of substantive rules that comprise the law of equity.") (footnotes omitted); id. at 218 ("Congress exercises the legislative power, not the judicial.").

122. See 28 U.S.C. $\S 1491(b)(1)(2000) ; 28$ U.S.C. $\S 1491$ (a)(3) (1996) ("To afford complete relief on any contract claim brought before the contract is awarded, the court shall have exclusive jurisdiction to grant declaratory judgments and such equitable and extraordinary relief as it deems proper, including but not limited to injunctive relief. In exercising this jurisdiction, the court shall give due regard to the interests of national defense and national security."); Administrative Dispute Resolution Act of 1996, P.L. 104-320, § 12(a), 110 Stat. 3875; The Federal Courts Improvement Act of 1982, Pub. L. No. 97-164, § 133, 96 Stat. 25, 41.

123. See supra note 45 .

124. See 28 U.S.C. $\$ 1491$ (b)(1) (2000); 28 U.S.C. $\$ 1491(a)(3)$ (1996).

125. See, e.g., IRC $\$ \S 6015$ (b) (equity of awarding innocent spouse relief from joint and several liability), 6511(h) (equitable tolling of statute of limitations on refund claims).

126. See infra notes 262-64 and accompanying text.

127. The innocent spouse defense allows an exception in certain cases from the rule of 
includes a provision requiring that "taking into account all the facts and circumstances, it is inequitable to hold the other individual liable for the deficiency in tax for such taxable year attributable to such understatement ."128 That use of the word "inequitable" likely refers to factors in determining the "fairness" of innocent spouse relief. This distinction does not affect the Tax Court's statutory power to decide the innocent spouse claim, but it may affect the Tax Court's power to consider equitable defenses. ${ }^{129}$

An analogous situation may occur with respect to claims with an equitable heritage. That is, Congress' grant to an Article I court of jurisdiction over an equity-based cause of action probably carries with it the power to consider related equitable defenses. On the other hand, if an action has equitable aspects only in the sense that it has a fairness-based history, that need not bring with it the power to hear equity-based defenses. For example, tax refund claims are heard both by the federal district courts, which are Article III courts, and the Court of Federal Claims, which is an Article I court. ${ }^{130}$ Numerous decisions by these courts state that the current refund suit derives from the action for indebitatus assumpsit for money had and received. As discussed below, that action is infused with equity-type fairness considerations. Yet that may not mean that the Court of Federal Claims can apply equitable recoupment or equitable estoppel in tax refund cases.

Similarly, in current legal practice, "general equitable powers," such as the power "to take jurisdiction over a matter not provided for by statute" may be distinguishable from the power to apply "equitable principles" such as

joint and several liability of spouses filing a joint tax return. See IRC $\$ \S 6013$ (d)(3) ("if a joint return is made, the tax shall be computed on the aggregate income and the liability with respect to the tax shall be joint and several."), 6015 (providing for innocent spouse relief).

128. IRC $\$ 6015(\mathrm{~b})(1)(\mathrm{D})$ (emphasis added).

129. See, e.g., Friedman v. Commissioner, 53 F.3d 523, 532 (2d Cir. 1995) (with respect to equity element, "[r] elevant factors include significant benefits received as a result of the understatements of the spouse claiming relief, any participation in the wrongdoing on the part of the 'innocent' spouse, and the effect of a subsequent divorce or separation.") (interpreting Code section 6013(e)(1)(D)); Pietromonaco v. Commissioner, 3 F.3d 1342, 1347 (9th Cir. 1993) (significant benefit in excess of normal support is a factor relevant to equity of granting innocent spouse relief); see also Regs. $\$ 1.6013-5$ (b) ("Whether it is inequitable to hold a person liable for the deficiency in tax ... is to be determined on the basis of all the facts and circumstances. In making such a determination a factor to be considered is whether the person seeking relief significantly benefitted, directly or indirectly, from the items omitted from gross income. However, normal support is not a significant 'benefit' for purposes of this determination.").

130. The Court of Federal Claims has an Article III history. Its predecessor, the Court of Claims, was an Article III court, with trial and appellate jurisdiction, until 1982. Stephen J. Legatzke, Note, The Equitable Recoupment Doctrine in United States v. Dalm: Where's the Equity?, 10 Va. Tax Rev. 861, 895 n.252 (1991). In 1982, Congress created the trial-level Claims Court under Article I. See Federal Courts Improvement Act of 1982, Pub. L. No. 97-164, \$\$ 105, $133,139,96$ Stat., at 26-28, 39-41, 42-44. At that time, Congress also renamed the court the United States Claims Court. See id. 
equitable estoppel. ${ }^{131}$ For example, the Supreme Court has stated that "the Court of Claims has no power to grant equitable relief."132 Subsequently, Congress provided the court with jurisdiction to afford equitable relief, including injunctive relief, in "any contract claim brought before the contract is awarded."133 During the life of that provision, the Supreme Court ruled that the Claims Court had jurisdiction only to award damages, not specific equitable relief, in a case involving review of the Department of Health and Human Services' administration of Medicaid. ${ }^{134}$ The Supreme Court stated, "The Claims Court does not have the general equitable powers of a district court to grant prospective relief." 135 The Court acknowledged both its prior statement that "the Court of Claims has no power to grant equitable relief" and Congress' subsequent grant of equitable powers with respect to a different type of action than the one before it. ${ }^{136}$

The distinction drawn by the Supreme Court with respect to the Court of Federal Claims is quite helpful in understanding the limits on the equitable powers of Article I courts. Article I courts have no general equitable powers or generalized ability to grant equitable relief purely from their existence as courts of law. However, to the extent that Congress affords to an Article I court jurisdiction over equitable causes of action or jurisdiction to grant equitable relief, the court has those powers unless the grant unconstitutionally infringes on Article III courts.

2. Equity in the Tax Court. -In general, the debate over the Tax Court's equitable powers has taken place in specific contexts with respect to specific equitable doctrines, most notably equitable recoupment and equitable estoppel. ${ }^{137}$ In addition, and most recently, the Tax Court has asserted jurisdiction over equitable innocent spouse relief despite statutory language that does not seem to grant such jurisdiction. ${ }^{138}$

131. Buchine v. Commissioner, 20 F.3d 173, 176-77 (5th Cir. 1994).

132. Richardson v. Morris, 409 U.S. 464, 465 (1973).

133. See 28 U.S.C. $\S 1491$ (a)(3) (1996); Administrative Dispute Resolution Act of 1996, Pub. L. No. 104-320, $\S 12$ (a), 110 Stat. 3875; The Federal Courts Improvement Act of 1982, Pub. L. No. 97-164, $\$ 133,96$ Stat. 25,41 (1982). That provision was deleted and replaced with a similar one in 1996. See 28 U.S.C. $\$ 1491$ (b)(1)(2000); Pub. L. No. 104-320, § 12(a), 110 Stat. 3874 (Oct. 19, 1996).

134. Bowen v. Massachusetts, 487 U.S. 879 (1988).

135. Id. at 905; see also Kanemoto v. Reno, 41 F.3d 641, 644-45 (Fed. Cir. 1994) ("The Court of Federal Claims is an Article I trial court of limited jurisdiction. . . . The remedies available in that court extend only to those affording monetary relief; the court cannot entertain claims for injunctive relief or specific performance, except in narrowly defined, statutorily provided circumstances not here pertinent.") (citation omitted).

136. Bowen, 487 U.S., at 905 n. 40 (1988).

137. See Dubroff, supra note 62, at 483-84.

138. See infra notes $265-75$ and accompanying text. 
a. The Equitable Recoupment Saga.- " [E]quitable recoupment allows a party to use a tax related claim, barred by the statute of limitations, as a defense to another party's timely tax-related claim, where the two claims arise out of the same transaction or taxable event." 139 It "is based upon the concept that 'one taxable event should not be taxed twice, once on a correct theory and once on an incorrect theory ... and that to avoid this happening the statute of limitations will be waived." 140

The Tax Court's power to consider equitable recoupment arguments has a long and winding history. Historically, the IRS took the position that it was not entitled to offset a barred deficiency against a timely refund claim. ${ }^{141}$ Its analysis was primarily statutory. ${ }^{142}$ However, in Lewis $v$. Reynolds, ${ }^{143}$ the Supreme Court allowed the IRS to avoid issuing a refund when it found a deficiency for the same tax year after the statute of limitations on assessment had run. Shortly thereafter, in Bull v. United States, ${ }^{144}$ a tax refund action, the Supreme Court recognized that although the taxpayer was the plaintiff, functionally he was defending a claim made by the government, ${ }^{145}$ and allowed him to use recoupment, thus modernizing the doctrine. ${ }^{146}$ Yet, with respect to the Board of Tax Appeals, the Supreme Court stated in 1943:

The Internal Revenue Code, not general equitable principles, is the mainspring of the Board's jurisdiction. Until Congress deems it advisable to allow the Board to determine the overpayment or underpayment in any taxable year other than the one for which a deficiency has been assessed, the Board

139. James E. Tiemey, Equitable Recoupment Revisited: The Scope of the Doctrine in Federal Tax Cases after United States v. Dalm, 80 Ky. L.J. 95, 101-02 (1991) (footnote omitted).

Equitable recoupment issues may result because the party seeking recoupment has not planned ahead to avoid the problem of a statute of limitations about to expire. See Burgess J.W. Raby \& William L. Raby, Equitable Recoupment-Maybe Not for Tax Court? 81 Tax Notes 87, 91 (1998) ("tax practitioners need to remember that the problem is caused by the statute of limitations. The best cure is usually the protective refund claim. This works much better than statute mitigation or equitable recoupment. File them early; file them often.").

140. Mann v. United States, 552 F. Supp. 1132, 1135 (N.D. Tex. 1982) (quoting Minskoff v. United States, 490 F.2d 1283, 1285 (6th Cir. 1974)).

141. See, e.g., L.O. 1095, I-1 C.B. 313 (1922).

142. Id. at 314.

143. 284 U.S. 281 (1933).

144. 295 U.S. 247,260 (1935) ("the usual procedure for the recovery of debts is reversed in the field of taxation.").

145. See Leandra Lederman, "Civil"izing Tax Procedure: Applying General Federal Learning to Statutory Notices of Deficiency, 30 U.C. Davis L. Rev. 183, 192-93 (1996).

146. John A. Lynch, Jr., Income Tax Statute of Limitations: Sixty Years of Mitigation Enough, Already!!, 51 S.C. L. Rev. 62, 113-15 (1996). 
must remain impotent when the plea of equitable recoupment is based upon an overpayment or underpayment in such other year. ${ }^{147}$

For years, Tax Court cases consistently expressed the view that the court lacked jurisdiction over equitable recoupment claims. ${ }^{148}$ In 1998, Congress considered granting the Tax Court jurisdiction over a refund action either related by subject matter to a pending deficiency action, or where the result in either action would affect the amount in controversy in the other action. ${ }^{149}$ The provision included language providing that the Tax Court's jurisdiction would "include any counterclaim, set-off, or equitable recoupment against (or for) the taxpayer." 150 That provision became part of the Technical and Miscellaneous Revenue Act of 1988 , but was deleted at conference without explanation. ${ }^{151}$

[J]udicial application of equitable recoupment historically evinces a strong desire to keep the equity genie in the bottle because a genie who possesses equitable powers threatens values dear to the law of taxation and, indeed, the entire federal system. These threatened values include the annual accounting principle, limitation of actions, and its esteemed relative, sovereign immunity. ${ }^{152}$

One problem for the Tax Court is that, unlike with respect to equitable estoppel, discussed below, there was and is a specific statutory barrier to the Board/Tax Court's consideration of equitable recoupment. ${ }^{153}$ Code section 6214 (b) provides that, in making an income tax or gift tax determination for a particular year or calendar quarter, the Tax Court has "no jurisdiction to determine whether or not the tax for any other year or calendar quarter has been overpaid or underpaid." 154 Arguably, that precludes equitable recoupment

147. Commissioner v. Gooch Milling \& Elevator Co., 320 U.S. 418, 422 (1943).

148. See e.g., Estate of Schneider v. Commissioner, 93 T.C. 568,570 (1989); Phillips Petroleum Co. v. Commissioner, 92 T.C. 885, 888-890 (1989); Poinier v. Commissioner, 86 T.C. 478, 490-491 (1986), aff'd, in part and rev'd, in part, 898 F.2d 917 (3d Cir. 1988); Estate of Van Winkle v. Commissioner, 51 T.C. 994,999-1000 (1969); Vandenberge v. Commissioner, 3 T.C. 321, 327-328 (1944), aff' d, 147 F.2d 167 (5th Cir. 1945); cf. Rev. Rul. 71-56, 1971-1 C.B. 404, 405 ("the Tax Court lacks jurisdiction to consider a plea of equitable recoupment").

149. See S. 2238 § 785, 100 th Cong., 2d. Sess., 134 Cong. Rec. $\$ 12344$ (daily ed., Sept. $12,1988)$.

150. Id.

151. H.R. Conf. Rep. No. 1104, 100th Cong.. 2d. Sess., 233-34 (1988).

152. Lynch, supra note 146, at 108 (footnote omitted).

at 485 .

153. See Revenue Act of 1926, ch. $27 \S 274(\mathrm{~g}), 44$ Stat. 56; Dubroff, supra note 62,

154. IRC $\S 6214(b)$. 
involving income taxes and gift taxes. ${ }^{155}$ In 1999, Congress considered adding a sentence to section 6214(b) that would grant the Tax Court equitable recoupment power. The provision was part of the Taxpayer Refund and Relief Act of 1999, which was vetoed by President Clinton. ${ }^{156}$

In United States v. Dalm, the Supreme Court stated that because Dalm had not raised the issue in her Tax Court petition, the Court had "no occasion to pass upon the question whether Dalm could have raised a recoupment claim in the Tax Court."157 In dissent, Justice Stevens echoed the majority's view that it was possible that the Tax Court did have equitable recoupment jurisdiction. ${ }^{158}$ Those statements provided an opening for the Tax Court to reconsider its power to apply equitable recoupment. ${ }^{159}$

In Estate of Mueller v. Commissioner (Mueller II), ${ }^{160}$ the Tax Court considered only the question of whether the Tax Court had jurisdiction to apply equitable recoupment. In Mueller II, the taxpayer-estate raised "the partial affirmative defense of equitable recoupment" with respect to a time-barred overpayment of income tax by the estate's residuary legatee, the Bessie I. Mueller Trust (Trust). ${ }^{161}$ Both the time-barred income tax overpayment and the estate tax deficiency were based on the estate's valuation of stock in the Mueller Company, which the IRS had contested. ${ }^{162}$ The IRS moved to dismiss the defense for lack of jurisdiction. ${ }^{163}$ The Tax Court held that it had jurisdiction to consider the affirmative defense of equitable recoupment when the defense is raised in a tax deficiency case over which it has jurisdiction. ${ }^{164}$ The Court stated, "in deciding this case, we may take into account all facts that

155. The counter-argument is that $\S 6214(\mathrm{~b})$ only precludes determination of prior years' income taxes in income tax cases, and prior years' gift taxes in gift tax cases, and that it does not apply if the two types of tax are different. This argument is based on the statute's use of the phrase "the tax," which seemingly refers to the same tax under consideration, and on its legislative history. For a discussion of the legislative history, see Estate of Bartels v. Commissioner, 106 T.C. 430,434 (1996).

156. H.R. 2448 \& 1343, H.R. Conf. Rep. 106-289 at 194.

157. United States v. Dalm, 494 U.S. 596, 611 n.8 (1990).

158. See id. at 615 n.3 (Stevens, J., dissenting).

159. See Estate of Mueller v. Commissioner, 101 T.C. 551, 553 (1993).

160. Id. There was a prior decision in Mueller that focused on valuation of Mueller Co. stock. See Estate of Mueller v. Commissioner, 63 T.C. Memo (CCH) 3,027, T.C. Memo (RIA) I 92,284 (1992). That opinion is referred to by the courts as Mueller I. See Estate of Mueller v. Commissioner, 107 T.C. 189, 191 (1996), aff d, on other grounds, 153 F.3d 302 (6th Cir. 1998), cert. denied, 525 U.S. 1140 (1999); see also Estate of Mueller v. Commissioner, 101 T.C. 551, 551 (1993).

161. Estate of Mueller, 101 T.C. at 551.

162. See Estate of Mueller, 107 T.C. at 190. In Mueller I, the Tax Court held "that the date-of-death value of the Mueller Co. stock was $\$ 1,700$ per share, as opposed to $\$ 1,505$ per share as reported on petitioner's estate tax return or $\$ 2,150$ as determined by respondent in the notice of deficiency." Estate of Mueller, 107 T.C. at 191.

163. Estate of Mueller, 101 T.C. at 551.

164. Id. at 560. 
bear on petitioner's deficiency and may apply equitable principles in so doing." 165 Essentially, the court's position was that it could consider any argument necessary to making a decision in the case.

In its decision in Mueller II, the Tax Court found that the statute that precluded jurisdiction over other tax years ${ }^{166}$ did not bar the application of equitable recoupment. ${ }^{167}$ Instead, the court focused on whether it had equity jurisdiction. It is not surprising that the court was reluctant to hold that it simply did not have the equitable power to consider the equitable recoupment argument. Easing into its holding that the court had jurisdiction over an equitable recoupment claim, the Tax Court in Mueller II referred to equitable recoupment as having "developed concurrently at common law and in equity,"168 citing a commentator who has been noted for his singularity in disputing recoupment's origins in equity. ${ }^{169}$ In fact, at common law, recoupment was narrowly applied to allow the defendant to reduce the amount owed to the plaintiff by prior payment or recovery with respect to the same claim. ${ }^{170}$ In addition, even then, "[t]he defense of recoupment was an innovation upon, or departure from, the strict rules of law, sanctioned by the courts for the purpose of doing equity between parties, where it could not be otherwise attained, or not without a circuitous and expensive process."171

Judge Chabot dissented in Mueller II, stating:

The majority do not reveal to us where in subtitle B, or anywhere else in the Internal Revenue Code, is the element of petitioner's tax that might be affected by possible application of equitable recoupment. Obviously, equitable recoupment does not affect the amount shown as the tax on the taxpayer's tax return. It appears that the doctrine of equitable recoupment does not affect what we have already described as the "sole issue for decision" in the instant case, or any other element of the Internal Revenue Code that is to be taken into account in determining the amount of any deficiency in the instant case. ... ${ }^{172}$

165. Id. at 556.

166. See IRC $\$ 6214$.

167. Estate of Mueller, 101 T.C. at 561.

168. Id. at 552 (citing McConnell, The Doctrine of Recoupment in Federal Taxation, 28 Va. L. Rev. 577, 579-581 (1942)).

169. Lynch, supra note 146, at $111 \mathrm{n} .297$ ("Unlike others who define this doctrine, Mr. McConnell disputes that its nature is equitable.").

170. Thomas W. Waterman, A Treatise on the Law of Set-Off, Recoupment, and Counter-Claim, $\$ \S 455-460$, at 476-480 (Baker, Voorhis \& Co. 1872).

171. Id. \$ 421, at 469 .

172. Estate of Mueller, 101 T.C. at 566 (Chabot, J., dissenting). 
Thus, Judge Chabot made the valid point that the application of equitable recoupment would neither affect the amount of deficiency nor result in an overpayment for the tax year, ${ }^{173}$ the linchpins of the Tax Court's subject matter jurisdiction in a tax deficiency case. ${ }^{174}$

In Mueller III, the Tax Court considered the actual application of equitable recoupment principles to the case. The court held that because equitable recoupment may only be used as a defense, and because, based on its valuation of the shares of the Mueller Company, ${ }^{175}$ the estate was entitled to an overpayment of estate tax, the doctrine did not apply to the case. ${ }^{176}$ This holding rendered Mueller II irrelevant to the ultimate result. ${ }^{177}$

On appeal, the Court of Appeals for the Sixth Circuit held that the Tax Court lacked jurisdiction to apply equitable recoupment. ${ }^{178}$ The Sixth Circuit found that

[A] deficiency redetermination sought in the Tax Court should not be confused with a refund suit filed in the district court. Whereas the deficiency redetermination is nothing more than the judicial review of an assessment made by an administrative agency, a refund suit is an "action brought to recover a tax erroneously paid, [which,] although an action at law is equitable in its function. It is the lineal successor of the common count indebitatus assumpsit for money had and received." 179

However, as discussed below, that analysis does not consider the similarities of the refund suit to the overpayment suit in Tax Court. ${ }^{180}$

Subsequent to the Sixth Circuit's adverse holding in Mueller, the Tax Court nonetheless applied equitable recoupment in three cases, Estate of Bartels v. Commissioner, ${ }^{181}$ appealable to the Seventh Circuit, Estate of Branson v. Commissioner, ${ }^{182}$ appealable to the Ninth Circuit, and Estate of Orenstein v. Commissioner, ${ }^{183}$ appealable to the Eleventh Circuit. In two of

173. See id. at 568 (Chabot, J., dissenting).

174. See IRC $\$ \S 6213,6214(\mathrm{~b})$.

175. See Estate of Mueller, 63 T.C. Memo (CCH) 3,027, T.C. Memo (RIA) ๆ 92,284 (1992); supra note 162.

176. Estate of Mueller, 107 T.C. at 199.

177. Prior to its decision in Mueller II, the Tax Court had already valued the Mueller Company stock at issue. See Estate of Mueller, 63 T.C. Memo (CCH) 3,027, T.C. Memo (RIA) If 92,284 (1992). It was that valuation, coupled with the IRS's allowance in the notice of deficiency of a credit for tax on prior transfers, that eliminated any deficiency in estate tax, and in fact entitled the estate to an overpayment. See Estate of Mueller, 107 T.C. at 191-192.

178. Estate of Mueller v. Commissioner, 153 F.3d 302 (6th Cir. 1998).

179. Id. at 304 (quoting Stone v. White, 301 U.S. 532 (1937)).

180. See infra notes 354-60 and accompanying text.

181. 106 T.C. 430 (1996).

182. 113 T.C. 6 (1999).

183. 79 T.C. Memo (CCH) 1971 (2000). 
these cases, the Tax Court had to address circuit court case law on the issue of equitable recoupment application in the Tax Court; Golsen v. Commissioner ${ }^{184}$ requires the Tax Court to apply circuit precedent "squarely in point."185

In Estate of Bartels v. Commissioner, Mr. and Mrs. Bartels had filed joint income tax returns for their 1981 and 1982 tax years. ${ }^{186}$ In 1990, after the death of both of the Bartels, the IRS issued notices of deficiency for those years, and their estates timely petitioned the Tax Court. ${ }^{187}$ The estates later conceded those income tax liabilities. ${ }^{188}$ However, Mr. Bartels' estate sought to recoup a time-barred estate tax overpayment against the income tax deficiency.

Mr. Bartels' estate had filed an estate tax return on February 21, $1990 .{ }^{189}$ It had reported a total estate tax liability of $\$ 3,582,245$, which it paid on February 20 and 21, and which was assessed on April 9, 1990. ${ }^{190}$ On November 18,1991 , the IRS assessed a deficiency in estate tax of $\$ 94,364$, plus interest of $\$ 17,094.88 .{ }^{191}$ The estate paid both amounts on September 18 , $1991 .^{192}$ On its return, the estate had not claimed any deduction for debts of the decedent to the IRS for income tax liabilities for the 1981 and 1982 tax years. ${ }^{193}$ Accordingly, on September 14, 1993, the estate filed an amended estate tax return, claiming additional deductions totaling $\$ 267,705.57,{ }^{194}$ which resulted in an overpayment of estate tax of $\$ 108,689 .{ }^{195}$ Because the estate had filed its amended return more than three years after its original return, the IRS allowed the refund claim only to the extent of estate tax paid within two years before the amended estate tax return was filed $(\$ 94,364) .{ }^{196}$ The IRS thus found that $\$ 14,325$ of the estate tax overpayment was barred by the statute of limitations. ${ }^{197}$ The taxpayers asserted in Tax Court that the amount of the federal income tax deficiencies should be reduced by the time-barred overpayment of estate tax, under the doctrine of equitable recoupment. ${ }^{198}$ The Tax Court held that it had jurisdiction to consider the equitable recoupment

184. 54 T.C. 742 (1970), aff'd, on other grounds, 445 F.2d 985 (10th Cir. 1971); cert. denied, 404 U.S. 940 (1971).

185. Id. at 757.

186. Estate of Bartels, 106 T.C. at 431.

187. Id. at 432.

188. Id.

189. Estate of Bartels, 106 T.C. at 432.

190. Id.

191. Id.

192. Id.

193. Id.

194. Id.

195. Id.

196. See id. at 433; IRC § 6511(a).

197. See Estate of Bartels, 106 T.C. at 433.

198. Id. 
argument, and granted the taxpayers' motion. ${ }^{199}$ In part, the court found that section 6214(b), which precludes Tax Court consideration of income or gift tax liability for any year not before the Court, did not preclude the court from allowing equitable recoupment of the estate tax overpayment against the income tax deficiency. ${ }^{200}$

The facts of Orenstein $v$. Commissioner ${ }^{201}$ parallel those of Estate of Bartels. The IRS issued notices of deficiency in income tax to the Orensteins with respect to their 1981 and 1982 tax years. ${ }^{202}$ After Mrs. Orenstein's death in 1983, Mr. Orenstein petitioned the Tax Court for a redetermination of the income tax deficiency. Mr. Orenstein died in $1993^{203}$ and his estate filed a return that did not reflect a deduction for pending 1981 and 1982 income tax liabilities. ${ }^{204}$ In 1998, the taxpayers' estates conceded the income tax deficiencies. Because a refund of estate taxes based on the deduction of the income tax liability was time-barred, the estates sought equitable recoupment of the barred estate tax overpayment against the conceded income tax deficiency. ${ }^{205}$

In Orenstein, the Tax Court considered Continental Equities, Inc. v. Commissioner, ${ }^{206}$ in which the Court of Appeals for the Fifth Circuit had stated, "the conclusion that the 1969 Tax Reform Act [establishing the Tax Court as an Article I court] did not grant the Tax Court equitable jurisdiction is inescapable. The courts that have addressed the issue are in agreement without [sic] conclusion that the Tax Court still does not possess jurisdiction over equitable claims."207 Nonetheless, the Tax Court did not feel bound by Continental Equities, Inc. because of the lack of factual similarity of the two cases, the intervening passage of two decades during which the understanding of equitable recoupment had evolved, and the Eleventh Circuit's decision in Bokum v. Commissioner ${ }^{208}$ that the Tax Court had jurisdiction to apply a different equitable doctrine, equitable estoppel..$^{209}$ Thus, in Orenstein, as in Bartels, the Tax Court allowed recoupment of the otherwise barred estate tax against the income tax deficiencies. ${ }^{210}$

199. Id. at 436.

200. Id. at 435 .

201. 79 T.C. Memo (CCH) 1971 (2000).

202. Id.

203. Id.

204. Id.

205. Id.

206. 551 F.2d 74 (5th Cir. 1977). Cases decided by the Court of Appeals for the Fifth Circuit prior to October 1, 1981, are considered binding precedent within the Eleventh Circuit. See Bonner v. City of Prichard, 661 F.2d 1206, 1209 (11th Cir. 1981).

207. Continental Equities, Inc., 551 F.2d at 84.

208. 992 F.2d 1136 (11th Cir. 1993), aff'g 58 T.C. Memo (CCH) 1183, T.C. Memo (RIA) ๆ 90,021 (1990).

209. Orenstein v. Commissioner, 79 T.C. Memo (CCH) 1971 (2000).

210. See id. 
Estate of Branson presented facts similar to those involved in the Mueller cases. In Branson, the taxpayer-estate had reported certain date-ofdeath values of the stock in two companies, Savings Bank of Mendocino County and Bank of Willits. ${ }^{211}$ The estate sold some of the shares in each company at a gain, and distributed the proceeds to the residuary legatee, who had assumed individual liability for the estate taxes. ${ }^{212}$ She also reported the gain on her Federal income tax return and paid the income tax due. ${ }^{213}$ The IRS determined a deficiency in estate tax liability based on higher valuations of the shares in each company. ${ }^{214}$ In a memorandum opinion, the Tax Court determined date-of-death fair market values that lay between the amounts asserted by the estate and the IRS. ${ }^{215}$ That resulted in a deficiency in estate tax and an overpayment of income tax on the gains from sale. ${ }^{216}$ Refund of the overpayment of income taxes was barred by the statute of limitations, so the estate asserted its entitlement to equitable recoupment, based on Estate of Mueller. ${ }^{217}$

In deciding Estate of Branson, the Tax Court considered Mohawk Petroleum Co. v. Commissioner, ${ }^{218}$ in which the Ninth Circuit had held that, under Gooch Milling \& Elevator Co., the Board of Tax Appeals lacked jurisdiction to consider equitable recoupment of income taxes. ${ }^{219}$ The Tax Court held that Gooch Milling, a case addressing the Board of Tax Appeals (an executive agency), did not apply to the Tax Court (an Article I court). Accordingly, it found that the Ninth Circuit lacked precedent squarely on point. ${ }^{220}$ The Tax Court then followed its decision in Mueller II, allowing recoupment. ${ }^{221}$

The Court of Appeals for the Ninth Circuit recently affirmed Estate of Branson, holding that the Tax Court had the power to apply equitable recoupment, and that it properly applied it in the Branson case. ${ }^{222}$ This decision has created a circuit split with the Court of Appeals for the Sixth Circuit. ${ }^{223}$ The Ninth Circuit's reasoning in Branson hinged on its view that it would be unfair to taxpayers not to have the option to raise an equitable recoupment claim in Tax Court, the sole forum not requiring advance payment of litigated taxes. The

211. Estate of Branson, 113 T.C. 6, 6 (1999), aff' d 264 F.3d 904 (9th Cir. 2001).

212. Id. at 7.

213. Id. at 7-8.

214. Id. at 9.

215. See Estate of Branson v. Commissioner, 78 T.C. Memo (CCH) 78, T.C. Memo (RIA) ๆ 99.231 (1999).

216. Estate of Branson, 113 T.C. at 9.

217. Id.

218. 148 F.2d 957, 959 (9th Cir. 1945), aff'g 47 B.T.A. 952 (1942).

219. See id. at 959.

220. Estate of Branson, 113 T.C. at 13.

221. See id. at 36.

222. Estate of Branson v. Commissioner, 264 F.3d 904 (9th Cir. 2001).

223. See Mueller v. Commissioner, 153 F.3d 302 (6th Cir. 1998). 
Branson court accordingly found a "presumption" of equivalent authority of the Tax Court and the district courts, and held that "[t]o rebut this presumption ... the Commissioner must find specific support in the provisions of the Tax Code ... ."224 Because the Ninth Circuit did not find a bar to equitable recoupment in the Code, ${ }^{225}$ it held that the Tax Court may apply equitable recoupment. This "parallelism fallacy" is debunked below. 226

The Ninth Circuit discussed Mueller in a footnote. ${ }^{227}$ It stated that its reading of section 6214 (b) disagreed with that of the Mueller court. It also seemed to distinguish Mueller on the ground that the income tax and estate tax in Mueller related to two different tax years, unlike in Branson..$^{228}$ Apparently, the Ninth Circuit found significant the fact that in Branson, the estate tax had been paid in 1992 (though the decedent died in 1991) ${ }^{229}$ and the income tax year in question was 1992 (though the income tax was paid in 1993). ${ }^{230}$ The court stated, "[w]e have no occasion to pass upon the question whether the Tax Court would have jurisdiction to consider an equitable recoupment claim where the tax sought to be recouped was from a previous tax year."231 However, this analysis is flawed because the estate tax is not an annual tax, so it is not assessed for a particular "tax year." It will be interesting to see whether the Supreme Court has an opportunity to consider this case.

The opinions in these cases were not without dissenters. Judge Chabot expressed his belief that the Tax Court lacks equitable recoupment authority. In his dissent in Estate of Branson, he made the point that "nothing in the concepts of a 'court', or a 'court of law', makes equitable recoupment an essential characteristic of a court, or of a court of law."232 He made a similar point in Mueller I:

224. Estate of Branson, 113 T.C. at 14.

225 . The Branson court correctly stated that $\$ 6214(\mathrm{~b})$ did not apply because it does not refer to estate taxes. Estate of Branson, 264 F.3d at 913.

226. See infra notes 301-319 and accompanying text.

227. See Estate of Branson, 264 F.3d at 913 n.5.

228. Id. ("We also note, however, that in Mueller the taxpayer sought recoupment of an income tax overpayment that was made in a different tax year from the estate tax deficiency before the Tax Court."); see also id. at 915 ("In this case, the taxpayer seeks to apply an income tax overpayment against an estate tax deficiency, both of which occurred in the same year."). Perhaps the strangest statement the court made in this regard is "[a]ppellee's estate tax deficiency and consequent income tax overpayment were both paid in the same tax year." Id. at 912. In fact, the estate tax was paid in 1992, and the income tax with respect to 1992 was paid in 1993 . See Estate of Branson v. Commissioner, 113 T.C. 6, 8-9 (1999). The Ninth Circuit apparently had a fundamental misunderstanding of the different nature of income taxes and estate taxes.

229. See Estate of Branson v. Commissioner, 113 T.C. at 6.

230. Id. at 9.

231. Estate of Branson v. Commissioner, 264 F.3d at 913 n.5.

232. Estate of Branson, 113 T.C. at 46 (Chabot, J., dissenting). 
In the context of considering whether the tax collector should refund to the taxpayer any specific amount of money that the taxpayer has paid to the tax collector, there has developed the concept of equitable recoupment as a doctrine that affects the "oughtness" of any such refund. Thus, it may be more productive of understanding to say that equitable recoupment fits into the refund jurisdiction of certain fora, and not that those fora have equitable recoupment jurisdiction. ${ }^{233}$ However, this approach has not prevailed.

b. Equitable Estoppel.-Equitable estoppel is broader than equitable recoupment. The application of equitable estoppel prevents one party from obtaining an advantage over the other party through misleading conduct. ${ }^{234}$ "The application of the doctrine ordinarily involves a decision not to follow general principles of the tax law because of the equities in a particular case and therefore courts are cautious in its use." 235 Equitable estoppel has four primary elements:

(1) The first party, with knowledge of the facts, communicates something to a second party in a misleading way.

(2) The second party reasonably relies on the communication.

(3) The second party would be materially harmed if the first party is permitted to assert a claim inconsistent with his earlier communication.

(4) The first party should have known that the second party would rely on the misleading communication. ${ }^{236}$

The Tax Court's use of equitable estoppel reflects the court's inconsistent approach to equitable doctrines in general. In some cases, the court applies equitable estoppel without analysis of its jurisdiction to do so. ${ }^{237}$ In other cases, the court asserts that it has jurisdiction to apply it, ${ }^{238}$ and in still other cases, the court has said that it lacks jurisdiction to apply it. ${ }^{239}$ Thus, there is some dispute over whether the Tax Court may use equitable estoppel. ${ }^{240}$ Equitable estoppel therefore provides a valuable springboard for consideration

233. Estate of Mueller, 101 T.C. at 567-68 (Chabot, J., dissenting).

234. Kennedy, supra note 80 , at 624 .

235. Dubroff, supra note 62, at 488 .

236. Kennedy, supra note 80 , at 624 .

237. See. e.g.. Graff v. Commissioner, 74 T.C. 743, 760-65(1980), aff d, 673 F.2d 784 (5th Cir. 1982); Bartel v. Commissioner, 54 T.C. 25 (1970); Hollman v. Commissioner, 38 T.C. 251, 260 (1962).

238. See e.g., Orenstein v. Commissioner, 79 T.C. Memo (CCH) 1971 (2000); Alderman v. Commissioner, 55 T.C. Memo (CCH) 86, T.C. Memo (RIA) ๆ 88,049 (1988).

239. See, e.g., Schwartz v. Commissioner, 40 T.C. 191, 193-94 (1963) (construing claim as claim for "pseudo-estoppel"); Lorain Ave. Clinic v. Commissioner, 31 T.C. 141, 164 (1958); see also Dubroff, supra note 62, at 491.

240. See Dubroff, supra note 62, at 492-93. 
of the Tax Court's equitable power in the absence of a statute specifically granting or denying that jurisdiction.

In some Tax Court cases, the court has used equitable estoppel, particularly against the taxpayer. ${ }^{241}$ In many other cases, it has refused to apply the doctrine either because one or more of the necessary elements were not present, ${ }^{242}$ or on the ground that it lacks equity jurisdiction. ${ }^{243}$ The Tax Court has been somewhat reluctant to apply estoppel against the government, ${ }^{244}$ for reasons that have nothing to do with whether or not it has equitable power; most courts are hesitant to estop the federal government. ${ }^{245}$

Some courts seem simply to have assumed without analysis that the Tax Court has the power to use equitable estoppel. ${ }^{246}$ By contrast, in Flight Attendants against UAL Offset $v$. Commissioner, ${ }^{247} \mathrm{Judge}$ Posner expressly held that the Tax Court has jurisdiction over equitable estoppel claims, noting that "[t]he argument that the Tax Court cannot apply the doctrines of equitable tolling and equitable estoppel because it is a court of limited jurisdiction is fatuous. All federal courts are courts of limited jurisdiction.,"248

241. See, e.g., Sangers Home for Chronic Patients, Inc. v. Commissioner, 72 T.C. 105 (1979) (taxpayer estopped); Herschlerv. Commissioner, 48 T.C. Memo (CCH) 1475, T.C. Memo (RIA) I 84,569 (1984) (taxpayer estopped); cf. Fredericks v. Commissioner, 126 F.3d 433 (3d Cir. 1997) (government estopped), rev'g 71 T.C. Memo (CCH) 2998.

242. See, e.g., Hofstetter v. Commissioner, 98 T.C. 695, 700 (1992); Kronish v. Commissioner, 90 T.C. 684 (1988); Boulez v. Commissioner, 76 T.C. 209, 214-15 (1981); Graff v. Commissioner, 74 T.C. 743, 761 (1980); Schwotzer v. Commissioner, 51 T.C. Memo (CCH) 902, T.C. Memo (RIA) ๆ 86,161 (1986).

243. See Dubroff, supra note 62 , at 488.

244. See, e.g., Hofstetterv. Commissioner, 98 T.C. 695, 700 (1992) (equitable estoppel is to be applied against the government only "with utmost caution and restraint.") (quoting Estate of Emerson v. Commissioner, 67 T.C. 612,617 (1977)); Boulez v. Commissioner, 76 T.C. 209, 214-15 (1981) (similarly quoting Emerson), aff'd, 810 F.2d 209 (D.C. Cir. 1987), cert. denied, 484 U.S. 896 (1987); Graff, 74 T.C. 743, 761 (1980) ("Although the doctrine of equitable estoppel is not inapplicable to the Federal Government, it has been applied to such Government with caution and only where justice and fair play require it."), aff'd, 673 F.2d 784 (5th Cir. 1982).

245. See, e.g., Kennedy v. United States, 965 F.2d 413, 417 (1992) ("This court, along with several other circuits, allows a private party to assert equitable estoppel against the government in a very narrow category of cases-when the traditional elements of estoppel are shown and there is affirmative misconduct on the part of the government.") (citing United States v. Asmar, 827 F.2d 907, 911 n.4 (3rd Cir. 1987)); Estate of Carberry v. Commissioner, 933 F.2d 1124,1127 (2d Cir. 1991) ("The doctrine of estoppel "is applied against the Government "with the utmost caution and restraint."”) (quoting Boulez v. Commissioner, 76 T.C. 209, 214-15 (1981)); see also Heckler v. Community Health Serv. Inc., 467 U.S. 51, 60 (1984) (expressly leaving open the possibility of a flat rule barring any estoppel against the government).

246. See, e.g., Boulez v. Commissioner, 810 F.2d 209, 218 n.68 (D.C. Cir. 1987), cert. denied, 484 U.S. 896 (1987), aff'g 76 T.C. 209, 214-17 (1981); Graff v. Commissioner, 673 F.2d 784, 785 (5th Cir. 1982), aff'g 74 T.C. 743, 760-65 (1980); Estate of Emerson v. Commissioner, 67 T.C. $612,617-18$ (1977).

247. Flight Attendants Against UAL Offset (FAAUO) and United Air Lines, Inc. v. Commissioner, 165 F.3d 572, 578 (7th Cir. 1999).

248. Id. 
Other courts have also held that the Tax Court may apply equitable estoppel. ${ }^{249}$ The Ninth Circuit has held that the Tax Court had the "equitable power to reform the two IRS Forms 872-A that were the subject of the deficiency determination before it." "250 Similarly, in Mayfair Minerals, Inc. $v$. Commissioner, ${ }^{251}$ the Fifth Circuit affirmed the Tax Court's holding that when the IRS allowed the statute of limitations on assessment to run because of the taxpayer's misleading returns, equitable estoppel prohibited the taxpayer from denying that the deductions were properly taken in the earlier years in which he had taken them.

Relying on the equitable estoppel line of authority, the Sixth Circuit held, in Reynolds $v$. Commissioner, that the Tax Court has judicial estoppel power. ${ }^{252}$ "The judicial estoppel doctrine protects the integrity of the judicial process by preventing a party from taking a position inconsistent with one successfully and unequivocally asserted by the same party in a prior proceeding."253 It prevents litigant game-playing through repudiation in one lawsuit of a ground successfully maintained in another lawsuit. ${ }^{254}$ The Reynolds holding is somewhat surprising, because, as discussed above, it was the Sixth Circuit in Estate of Mueller ${ }^{255}$ that reversed the Tax Court's holding that it may apply equitable recoupment. ${ }^{256}$ However, Mueller involved a statutory bar to equitable recoupment, as well as Supreme Court authority (with respect to the Board of Tax Appeals); ${ }^{.57}$ Reynolds did not involve either of these barriers. ${ }^{258}$

\section{c. Equitable Innocent Spouse Relief.-Certain Internal Revenue}

Code sections expressly authorize the Tax Court to consider equitable concerns. ${ }^{259}$ For example, after the Supreme Court refused to apply equitable tolling in a 1997 statute of limitations case, ${ }^{260}$ Congress amended the statute of limitations on refund claims to allow equitable tolling of the statute in certain

249. See, e.g., Bokum v. Commissioner, 992 F.2d 1136, 1140-41 (11th Cir. 1993) (dictum) ("If the Tax Court lacked authority to entertain a claim of equitable estoppel . . . taxpayers would essentially be denied the right to challenge deficiencies in the Tax Court if they wanted to assert an equitable estoppel claim. This would be an unfair choice to pose to taxpayers, and would undermine the purpose of the Tax Court.").

250. Kelley v. Commissioner, 45 F.3d 348, 352 (9th Cir. 1995).

251. 456 F.2d 622 (5th Cir. 1972).

252. Reynolds v. Commissioner, 861 F.2d 469, 472 (6th Cir. 1988).

253. Id.

254. See, e.g., Ogden Martin Systems v. Whiting Corp., 179 F.3d 523, 526 (7th Cir.

1999); Levinson v. United States, 969 F.2d 260, 264 (7th Cir. 1992).

255. Estate of Mueller v. Commissioner, 153 F.3d 302 (6th Cir. 1998), cert. denied,

525 U.S. 1140 (1999).

256. Id.

257. See id. at 305-306.

258. See generally Reynolds v. Commissioner, 861 F.2d 469 (6th Cir. 1988).

259. See supra note 128 and accompanying text.

260. United States v. Brockamp, 519 U.S. 347 (1997). 
situations. ${ }^{261}$ Similarly, section 6015 , and its predecessor, section 6013(e), affording an innocent spouse defense to joint and several liability for taxes, ${ }^{262}$ also have equitable elements. Code section 6015 (b) provides, in part:

(1) In general. Under procedures prescribed by the Secretary, if-

(A) a joint return has been made for a taxable

year;

(B) on such return there is an understatement of tax attributable to erroneous items of one individual filing the joint return;

(C) the other individual filing the joint return establishes that in signing the return he or she did not know, and had no reason to know, that there was such understatement;

(D) taking into account all the facts and circumstances, it is inequitable to hold the other individual liable for the deficiency in tax for such taxable year attributable to such understatement; and

(E) the other individual elects (in such form as the Secretary may prescribe) the benefits of this subsection not later than the date which is 2 years after the date the Secretary has begun collection activities with respect to the individual making the election, then the other individual shall be relieved of liability for tax (including interest, penalties, and other amounts) for such taxable year to the extent such liability is attributable to such understatement. ${ }^{263}$

Statutorily, the Tax Court has jurisdiction over such an innocent spouse claim, ${ }^{264}$ and therefore must consider the equities of the facts and circumstances.

The content of subsection (b) of section 6015 contrasts with that of subsection (f), which provides for innocent spouse relief based on equity:

Secretary, if-

(f) Equitable relief. Under procedures prescribed by the

(1) taking into account all the facts and circumstances, it is inequitable to hold the individual liable for any unpaid tax or any deficiency (or any portion of either); and

(2) relief is not available to such individual under subsection (b) or (c), the Secretary may relieve such individual of such liability. ${ }^{265}$

This section arguably reflects the individualized justice without explicit standards that is the hallmark of equity. ${ }^{266}$

261. See IRC § 6511(h).

262. See IRC § 6013(d)(3).

263. IRC $\S 6015$ (b)(1) (emphasis added).

264. See IRC $\$ 6015(e)(1)(A)$ (emphasis added).

265. IRC \& 6015(f).

266. See supra note 80 and accompanying text.

The IRS quickly produced a list of the facts and circumstances it considered appropriate to consider. See Rev. Proc. 2000-15, 2000-5 I.R.B. 447. 
If the Code provides the Tax Court with jurisdiction to consider section 6015(f) claims, then the Tax Court may exercise the discretion provided. However, the subsection of section 6015 providing the Tax Court with jurisdiction over innocent spouse claims seemingly does not provide for review of a denial of section $6015(f)$ equitable relief:

(e) Petition for review by Tax Court.

(1) In general. In the case of an individual who elects to have subsection (b) or (c) apply-

(A) In general. The individual may petition the

Tax Court (and the Tax Court shall have jurisdiction) to determine the appropriate relief available to the individual under this section . . . ${ }^{267}$

Commentators considering subsection (e) soon after its enactment generally concluded that the Tax Court did not have jurisdiction over denials of section 6015(f) relief in light of the language italicized above. ${ }^{268}$ Nonetheless, in three recent cases the Tax Court asserted that it had such jurisdiction, so long as it was also exercising jurisdiction over a claim under section 6015(b) or (c)..$^{269}$ The Tax Court noted, "where a taxpayer elects to have either subsection (b) or (c) apply, the taxpayer 'may petition the Tax Court (and the Tax Court shall have jurisdiction) to determine the appropriate relief available to the individual under this section'."270 The court found that the phrase "this section" in section $6015(\mathrm{e})(1)(\mathrm{A})$ referred to all of section 6015."271

Surprisingly, the IRS quickly acquiesced in the Tax Court's assertion of jurisdiction over section $6015(\mathrm{f})$ claims, ${ }^{272}$ reversing its prior position that the IRS's determination of whether to afford equitable innocent spouse relief was not subject to judicial review. ${ }^{273}$ In fact, it found that the Tax Court has jurisdiction over section 6015 (f) claims regardless of whether the taxpayer has also claimed relief under subsections (b) or (c), ${ }^{274}$ a reading arguably inconsistent with the language of the statute. ${ }^{275}$

267. IRC $\S 6015(\mathrm{e})(1)(\mathrm{A})$ (emphasis added).

268. See, e.g., Leslie Book, The New Collection Due Process Taxpayer Rights, 86 Tax Notes 1127, 1143 (2000); Toni Robinson \& Mary Ferrari, The New Innocent Spouse Provision: "Reason and Law Walking Hand in Hand?", 80 Tax Notes 835, 849 n.88 (2000); see also Field Serv. Adv. No. 199929019 (1999), 1999 F.S.A. LEXIS 110.

269. See Charlton v. Commissioner, 114 T.C. 333 (2000); Fernandezv. Commissioner, 114 T.C. 324 (2000), action on decision, 2000-06 (May 12, 2000); Butler v. Commissioner, 114 T.C. $276(2000)$.

270. Butler, 114 T.C. at $289-90$.

271. Id.

272. See IRS Notice N(35)000-338 (June 5, 2000), 87 Tax Notes 1612 (June 19, 2000). This Notice was issued about five weeks after the Tax Court's first section 6015(f) decision, Butler v. Commissioner, 114 T.C. 276 (2000).

273. See, e.g., Field Serv. Adv. No. 199929019 (1999), 1999 F.S.A. LEXIS 110.

274. IRS Notice N(35)000-338 (June 5, 2000), 87 Tax Notes 1612 (June 19, 2000).

275. See IRC $\S 6015(e)(1)$. 


\section{The Tax Court: Does it Have Equitable Powers?}

The Tax Court has expressly recognized that it "is a court of limited jurisdiction, and ... may exercise ... jurisdiction only to the extent authorized by Congress." ${ }^{276}$ Accordingly, as Congress has never specifically granted the Tax Court equitable powers, ${ }^{277}$ one would expect the Tax Court to lack such powers. And in fact, traditionally, the Tax Court had held that, as a court created by statute under Article I of the Constitution, it lacks "equity jurisdiction."278 Moreover, the United States Supreme Court has stated that "the Tax Court is a court of limited jurisdiction and lacks general equitable powers." 279

Nonetheless, as the discussion above demonstrates, over time, the Tax Court began to make use of equitable doctrines. ${ }^{280}$ In fact, in a 1989 decision, Woods v. Commissioner, ${ }^{281}$ in support of its decision to apply equitable principles and reform a Form 872-A, the Tax Court listed numerous doctrines that it had previously applied, and that it considered to be grounded in equity. ${ }^{282}$

276. See Fernandezv. Commissioner, 114 T.C. 324, 328 (2000); Gati v. Commissioner, 113 T.C. 132, 133 (1999); Yuen v. Commissioner, 112 T.C. 123, 124 (1999); Bourekis v. Commissioner, 110 T.C. 20, 24 (1998).

277. As one commentator has noted, "[0]ver six decades have passed since Congress created the Tax Court, and, as yet, Congress has not authorized equity jurisdiction." Legatzke, supra note 130 , at 894 .

278. See, e.g., Estate of Van Winkle v. Commissioner, 51 T.C. 994, 999-1000 (1969) (Tax Court does not have jurisdiction over equitable recoupment claim); Vandenberge v. Commissioner, 3 T.C. 321, 327-28 (1944) (same), aff'd, 147 F.2d 167 (5th Cir. 1945); Payson v. Commissioner, 6 T.C. Memo (CCH) 590, T.C. Memo (RIA) I 47,147 (1947) ("Respondent points out that petitioner seeks to invoke the doctrine of equitable estoppel and that this Court is without general equity jurisdiction."); cf. Phillips Petroleum Co. v. Commissioner, 92 T.C. 885, 889 (1989) ("the Court may not "exercise "general equitable principles" to take jurisdiction over a matter not provided for by statute.") (quoting Woods v. Commissioner, 92 T.C. 726, 787 (1989)); Donerv. Commissioner, 48 T.C.Memo (CCH) 1276, T.C. Memo (RIA) ๆ 84,528 (1984) ("We are satisfied that we should not . . . apply the general equitable principle asserted by petitioner that the Federal government should not be permitted to profit from its mistakes.").

In general, "equity jurisdiction" is a court's power to hear certain civil actions according to the procedures that were applied in courts of equity, and to resolve them under equitable rules. Black's Law Dictionary 856 (7th ed. 1999).

279. Commissioner v. McCoy, 484 U.S. 3, 7 (1987).

280. See, e.g., Estate of Mueller v. Commissioner, 101 T.C. 551, 553 (1993) (equitable recoupment); Orenstein v. Commissioner, 79 T.C. Memo (CCH) 1971 (2000) (equitable estoppel); Alderman v. Commissioner, 55 T.C. Memo (CCH) 86, T.C. Memo (RIA) I] 88.049 (1988) (same).

281.92 T.C. 776 (1989).

282. See id. at 784 ("we have applied the equity-based principles of waiver, duty of consistency, estoppel, substantial compliance, abuse of discretion, laches, and the tax benefit rule.") (footnotes omitted). 
Given the Tax Court's evolution from an executive agency to an Article I court with increasingly broad jurisdiction, ${ }^{283}$ it may not be surprising that the Tax Court has sought to take on as many of the powers of an Article III court as possible. Of course, the judges of the Tax Court do not all think with one mind. Recently, Tax Court cases have reflected express disagreement among the judges of the Tax Court over the extent of the court's equitable powers. ${ }^{284}$ Yet, a majority of the Tax Court considers the Tax Court to have at least some equitable power despite the lack of statutory authorization. ${ }^{285}$ Several Tax Court judges apparently believe that the Tax Court may exercise the full panoply of equitable powers. In a concurring opinion in which Judges Parr, Foley, Vasquez, Thornton, and Marvel joined, Judge Laro stated: ${ }^{286}$

The U.S. Tax Court is a court of law that, like the U.S. District Courts, has the authority to apply equitable principles such as equitable recoupment. ... I write separately to emphasize the fact that this Court, although different from District Courts in a few regards, the most obvious of which is that District Courts were created under Article III of the U.S. Constitution whereas this Court was created under Article I of the U.S. Constitution, is a court of law that has the authority to apply all of the judicial powers of a District Court. ${ }^{287}$

283. See supra notes 35-57 and accompanying text.

284. See, e.g., Estate of Branson v. Commissioner, 113 T.C. 6 (1999) (equitable recoupment case with majority opinion, two concurrences and one dissent); see supra notes 276282 and accompanying text.

285. See supra notes 280-84; infra note 287 and accompanying text.

Since the famous case of Marbury v. Madison, 5 U.S. 137 (1803), courts have opined on their own jurisdiction over matters before them, and asserted jurisdiction over those matters. Courts generally have been loath to relinquish jurisdiction over cases before them. See, e.g., Laura S. Fitzgerald, Beyond Marbury: Jurisdictional Self-Dealing In Seninole Tribe, 52 Vand. L. Rev. 407, 408-409 (1999) ("The [Supreme] Court ruled in its own favor each time it decided an overt question about the federal 'judicial Power' vested by Article III, consistently voting to fortify the Court's status within the Constitution's structure for the separation of powers, often at Congress' direct expense.") (footnotes omitted). In that light, the Tax Court's actions are unsurprising.

286. With the exception of Judge Parr, all of these judges have been appointed since 1993. Judge Parr, appointed in 1985, is the author of the Dorchester concurrence expressing the view that the Tax Court has the power to refuse to enter a bilateral settlement agreement, in the interest of justice. See Dorchester Indus. v. Commissioner, 108 T.C. 320, 343 (1997) (Parr, J., concurring).

287. Estate of Branson v. Commissioner, 113 T.C. 6, 41 (1999) (Laro, J., concurring). 
It is undeniable that the Tax Court is a court of law. ${ }^{288}$ It became a court of law in 1969, when Congress made it a legislative court under Article I of the Constitution. ${ }^{289}$ Yet, not all courts of law are governed by Article III of the Constitution. As an Article I court, the Tax Court is subject to constitutional and statutory limitations not applicable to Article III courts. ${ }^{290}$ Thus, finding that the Tax Court is a "court of law" does not resolve whether the Tax Court has the authority to apply equitable doctrines.

Judge Hamblen has stated, somewhat more modestly, "[w]hile we cannot expand our jurisdiction through equitable principles, we can apply equitable principles in the disposition of cases that come within our jurisdiction."291 This statement was quoted in Judge Beghe's majority opinion in Estate of Mueller v. Commissioner ${ }^{292}$ in which 13 judges joined, including Judges Parr and Laro. ${ }^{293}$ Judge Hamblen's statement that the Tax Court cannot expand its jurisdiction through the use of equity is uncontrovertable. Yet, it does not determine the issue of what constitutional limits Article I may place on the Tax Court's use of equity in cases before it.

A court does not acquire jurisdiction by simply asserting that it has jurisdiction. ${ }^{294}$ Even if a court has applied equitable doctrines without reversal on appeal, that does not necessarily mean that the court acted constitutionally or within its jurisdiction. In addition, as discussed above, judges may try to maximize power through their decisions. ${ }^{295}$ Accordingly, assertions in Tax

288. See Freytag, 501 U.S. at 888-89 (Tax Court is a "court of law" within the meaning of the Appointments Clause of Article II of the Constitution); cf. Estate of Branson, 113 T.C. at 41 (1999) (Laro, J., concurring) ("The United States Tax Court is a court of law that, like the United States District Courts, has the authority to apply equitable principles such as equitable recoupment."); see also Steven J. Willis, Sixth Circuit Decision on Equitable Recoupment Criticized, 81 Tax Notes 361, $370 \mathrm{n} .52$ (1998) ("As an Article I court, the Tax Court is a true court.").

Surprisingly, before Freytag was decided, the Second Circuit had held that the Tax Court was not a court of law but rather an executive agency, at least in part. Samuels, Kramer \& Co.v. Commissioner, 930 F.2d 975 (2d Cir. 1991). Although the Second Circuit recognized "that Congress intended to establish a "court' pursuant to its Article I authority," it nonetheless stated that it did "not find the legislative history to indicate definitively where in our constitutional scheme Congress intended to place this adjudicatory body." Id. at 991.

289. See Tax Reform Act of 1969, Pub. L. No. 91-172, § 951, 83 Stat. 487, 730.

290. See Estate of Rosenberg v. Commissioner, 73 T.C. 1014, 1017-18 (1980) ("The Tax Court has only such jurisdiction as is conferred upon it by statute. It has no jurisdiction to exercise the broad common law concept of judicial power invested in courts of general jurisdiction by Article III of the Constitution.").

291. Berkery v. Commissioner, 90 T.C. 259, 270 (1988) (Hamblen, J., concurring).

292. Estate of Mueller v. Commissioner, 101 T.C. 551, 557 (1993).

293. See id. at 561.

294. "A court cannot write its own jurisdictional ticket." Zerand-Bernal Group v. Cox, 23 F.3d 159, 163 (7th Cir. 1994); see also Cox v. Court of Common Pleas, 537 N.E. 2d 721, 725 (Ohio Ct. App. 1988) ("no matter how 'just' the cause, a court cannot confer jurisdiction upon itself to correct a perceived wrong.").

295. See supra note 12 and accompanying text. 
Court cases that the Tax Court has equitable power must be considered skeptically because Tax Court judges may consider it to be in the court's best interest both to actively expand the Court's jurisdiction and not to surrender jurisdiction over matters that come before the court.

The Tax Court's actions are consistent with this premise. For example, decided cases, including those settled after docketing, are entered by the court. ${ }^{296}$ In fact, unlike in District Court, once a taxpayer properly commences a case in Tax Court, only the court can remove the case from its jurisdiction. Thus, the Tax Court refuses to allow voluntary dismissal ${ }^{297}$ or "removal" to District Court. ${ }^{298}$ Although it rarely does so, the Tax Court may also refuse to enter as a decision a full concession by one party if that concession is rejected by the other party, who wants to litigate the case. ${ }^{299}$ Four Tax Court judges have concurred in the view that the Tax Court may refuse to enter as a decision a bilateral settlement agreement if the interests of justice require that. ${ }^{300}$

\section{A. The Parallelism Fallacy}

Part of what may underlie the Tax Court's assertion of equitable power is the recognition that the Tax Court shares jurisdiction with at least two courts, one of which clearly may apply equitable doctrines in tax cases. The United States District Courts and Court of Federal Claims may both hear federal tax cases. The District Courts, having been formed under Article III, have equitable powers. ${ }^{301}$ From the perspective of a tax lawyer or a Tax Court judge, it may be difficult to see why forum choice may affect the outcome simply because some courts have equitable powers and others may not. ${ }^{302}$ Even Judge Posner has used this approach to uphold Tax Court jurisdiction over equitable estoppel claims. In Flight Attendants Against UAL Offset, ${ }^{303}$ he stated, "[w]e are given

296. See Leandra Lederman, Which Cases Go to Trial?: An Empirical Study of Predictors of Failure to Settle, 49 Case W. Res. L. Rev. 315, 327 n.47 (1999).

297. See Wellman v. Commissioner, 49 T.C. Memo (CCH) 866, T.C. Memo (RIA) If 85,097 (1985) ("this Court has no procedure which authorizes or permits a party to unilaterally withdraw a petition once filed.").

298. Tuckett v. Commissioner, 46 T.C. Memo (CCH) 1413, T.C.Memo (RIA) $\mid 86,575$ (1983); Dorl v. Commissioner, 57 T.C. 720, 722 (1972), aff'd, 507 F.2d 406 (2d Cir. 1974).

299. See, e.g., Smith v. Commissioner, 78 T.C. 350 (1982) (taxpayer's attempted full concession reflected in case transcript), aff'd, 820 F.2d 1220 (4th Cir. 1987) (unpublished op.); LTV Corp. v. Commissioner, 64 T.C. 589 (1975). For further discussion of this issue, see Lederman, supra note 18.

300. See Dorchester Indus. v. Commissioner, 108 T.C. 320, 343 (1997) (Parr, J., concurring). Judge Parr was joined by Judges Chabot, Jacobs, and Laro. Id.

301. See U.S. Const. art. III. The bankruptcy courts also decide tax issues.

302. Cf. Willis, supra note 288, at 368 ("The [Sixth Circuit in Mueller] also did not deal with the patent unfairness of denying Tax Court equitable jurisdiction -and the silly games it prompts.").

303. Flight Attendants Against UAL Offset (FAAUO) and United Air Lines, Inc. v. Commissioner, 165 F.3d 572 (7th Cir. 1999). 
no reason to suppose that statutes of limitations are intended to be administered differently in the Tax Court than in the federal district courts, which share jurisdiction in federal tax cases with the Tax Court." 304

Yet Tax Court and refund court procedures and outcomes often differ - even with respect to statutes of limitations. ${ }^{305}$ That is, there are tax cases that are timely in one forum but not in another. The Supreme Court's decision in Commissioner v. Lundy ${ }^{306}$ provides an example of this situation. Lundy argued to the Court that the Court's interpretation of section 6512 would result in a shorter statute of limitations applicable to his overpayment claim in Tax Court than in District Court. ${ }^{307}$ The Court responded to this argument as follows:

We assume without deciding that Lundy is correct, and that a different limitations period would apply in district court, but nonetheless find in this disparity no excuse to change the limitations scheme that Congress has crafted. The rules governing litigation in Tax Court differ in many ways from the rules governing litigation in the district court and the Court of Federal Claims. Some of these differences might make the Tax Court a more favorable forum, while others may not. ${ }^{308}$

The Court pointed out that the "full payment" rule of the refund fora ${ }^{309}$ does not apply in Tax Court, and that in Tax Court the taxpayer is deemed to have filed a refund claim stating the grounds on which he seeks an overpayment of tax; ${ }^{310}$ in the refund courts, undue "variance" from the grounds of the claim may result in dismissal. ${ }^{311}$

Tax Court and refund court procedures differ in other key ways, as well. One important example is that the burden of proof in Tax Court deficiency cases differs from the burden of proof in refund courts, at least in the absence of a burden shift under section 7491, as discussed below. ${ }^{312}$ In a Tax Court deficiency case, the taxpayer need not prove the dollar amount. An additional difference is that the specifics of the burden of proof in Tax Court

304. Id. at 578 (citations omitted).

305. See infra notes 306-11 and accompanying text.

306. 516 U.S. 235 (1996).

307. See id. at 251.

308. Id. at 252.

309. See supra note 52 and accompanying text.

310. Id.

311. See, e.g., Real Estate-Land Title \& Trust Co. v. United States, 309 U.S. 13, $17-18$ (1940); McDonnell v. United States, 180 F.3d 721, 722 (6th Cir. 1999); Charter Co. v. United States, 971 F.2d 1576, 1579 (11th Cir. 1992); see also Regs. § 301.6402-2(b)(1)(requiring refund claim to state grounds for refund with specificity).

312. See IRC $\$ 7491$ (allowing burden of proof to be shifted to the IRS in tax litigation in any forum if the taxpayer meets several prerequisites). 
cases emphasize the notice of deficiency. ${ }^{313}$ Access to the Tax Court in a deficiency case requires issuance to the taxpayer of a notice of deficiency in income, estate, or gift tax..$^{314}$ No notice of deficiency is required for access to a refund forum. ${ }^{315}$

In Tax Court cases in which section 7491 does not apply, the Tax Court's burden of proof rule provides, in part:

The burden of proof shall be upon the [taxpayer], except as otherwise provided by statute or determined by the Court; and except that, in respect of any new matter, increases in deficiency, and affirmative defenses, pleaded in the answer, it shall be upon the [IRS]. . . . ${ }^{316}$

New matters and increases in deficiency both refer to matters raised by the IRS after the notice of deficiency was mailed. ${ }^{317}$ Code section 6212 prohibits the IRS from avoiding the effect of this rule by mailing a second notice of deficiency to a taxpayer for the same tax and tax year with respect to which he petitioned the Tax Court. ${ }^{318}$ Because the notice of deficiency is largely irrelevant in refund litigation, the refund courts provide for no such burden shift.

Equal access to the Tax Court is not required by the Constitution; numerous courts have held that there is no due process requirement of access to a pre-assessment forum. ${ }^{319}$ Therefore, differences in outcome between similar cases in the Tax Court and the refund courts, even those resulting from different procedures in the two courts, are constitutionally permissible.

The facts that different procedures are permissible in Tax Court and the federal district courts, and that the differences may result in a different outcome, suggest that it is constitutionally permissible for equity to be available in Article III courts and not in the Tax Court. Accordingly, if the Tax Court is going to apply equitable principles, it must find a specific source of the power to do so.

313. See Tax Court Rule 142(a).

314. See IRC $\$ 6213$.

315. See Lederman and Mazza, supra note 51, at 350.

316. See Tax Court Rule 142(a)(1).

317. See Lederman, supra note 145, at 199, 227.

318. See IRC § 6212(c).

319. See, e.g., Lewin v. Commissioner, 569 F.2d 444, 445 (7th Cir. 1978); Brown v. Lethert, 360 F.2d 560, 562 (8th Cir. 1966): Cohen v. United States, 297 F.2d 760, 772 (9th Cir. 1962); Whittemore v. United States, 1992 U.S. Dist. LEXIS 10243 (N.D. Ohio 1992); see also Fendler v. Commissioner, 441 F.2d 1101, 1103 (9th Cir. 1971) ("The taxpayer has an opportunity for review of his tax liability in the district court, after payment, in a refund proceeding. ... There is no denial of due process."). 


\section{B. Possible Sources of Power to Apply Equitable Principles}

1. Four Categories of Cases.-Cases involving the extent of the Tax Court's equity jurisdiction may be divided into four categories. The first category reflects an uncontroversial absence of jurisdiction. The Tax Court itself recognizes that it cannot simply create such things as new deductions or exclusions from income through the use of equity. ${ }^{320}$ Professor Harold Dubroff aptly terms such taxpayer requests as "pleas for remedial legislation." 321 Such pleas must be directed to Congress, not a court - not even an Article III court. Courts have no power to enact statutes.

The second category involves a jurisdictional grant by Congress. As discussed above, in cases in which Congress has expressly granted the Tax Court authority to do equity, the Tax Court presumptively may do so. That is, an express statutory grant of equitable power to an Article I court is presumptively constitutional. The declaratory judgment action available in certain Tax Court cases ${ }^{322}$ falls in this category. Considering the equities in providing innocent spouse relief and equitable tolling of the statute of limitations ${ }^{323}$ may be additional examples.

The third category, a variation on the second, involves instances in which the governing statute requires interpretation to ascertain its intent. In section 6015 (e), Congress expressly gave the Tax Court jurisdiction over IRS denials of relief under section 6015(b) and (c), but was silent as to whether the

320. See Paxman v. Commissioner, 50 T.C. 567, 576 (1968) (Tax Court could not authorize an equitable deduction for home improvements to offset gross income from a prize awarded based on the improvements). The court stated,

[W] do not regard it as necessary to discuss the question whether the allowance of deduction would or would not be equitable, it being our opinion that it is sufficient to say that not only is the Tax Court not a court of equity but that petitioners, in effect, are asking us to legislate changes in the statute as enacted by Congress. The proper forum for a petition or plea of that kind is Congress. The power to legislate is exclusively the power of Congress and not of this Court or any other court.

Id. at 576-77.

321. Dubroff, supra note 62 , at 483.

322. See, e.g., Green v. Mansour, 474 U.S. 64, 72 (1985) ("The propriety of issuing a declaratory judgment may depend upon equitable considerations"); AbbottLabs. v. Gardner, 387 U.S. 136, 155 (1967) ("the declaratory judgment and injunctive remedies are equitable in nature, and other equitable defenses may be interposed."); see also Charles A. Rees, Preserved or Pickled?: The Right to Trial by Jury after the Merger of Law and Equity in Maryland, 26 U. Balt. L. Rev. 301, 451 (1997) ("Before the merger of Law and Equity, the declaratory judgment was available at Law as well as in Equity. After merger, the declaratory judgment is difficult to characterize as being either legal or equitable.") (footnotes omitted).

323. IRC $\$ 6511(\mathrm{~h})$ does not itself mention the words "equity" or "equitable." It is entitled, "[r]unning of periods of limitation suspended while taxpayer is unable to manage financial affairs due to disability," and provides guidelines for such a suspension. See IRC $\S 6511(\mathrm{~h})$. It is the Supreme Court case that was overruled by $\S 6511(\mathrm{~h})$ that used the term "equitable tolling." See United States v. Brockamp, 519 U.S. 347, 348 (1997). 
court had such jurisdiction over denials of relief under the purely equitable provision, section $6015(\mathrm{f}) .^{324}$ The IRS and commentators interpreted the statute to mean that the Tax Court did not have jurisdiction over section $6015(\mathrm{f})$ claims. ${ }^{325}$ However, once the Tax Court asserted that it did have such jurisdiction, the IRS acquiesced..$^{326}$ Yet, the Tax Court does not have jurisdiction just because it says so. ${ }^{327}$ The question is whether Congress in fact authorized the Tax Court to take jurisdiction over equitable innocent spouse relief. If it did, then, as with category two, the grant presumptively is constitutionally permissible.

Although the Tax Court's interpretation of section 6015(e) was not the one reached by initial commentators, and may not have been Congress's intent, it is a valid reading of an ambiguous statute. However, in one case, the Tax Court went so far as to amend the taxpayer's petition sua sponte to reassert a claim for innocent spouse relief under subsections (b) and (c), despite the taxpayer's concession at trial that she was not eligible for relief under those subsections. ${ }^{328}$ This seems to go further than Congress intended; it is unlikely it intended that the Tax Court consider section 6015(f) claims when neither section 6015 (b) or (c) were in issue. Nonetheless, Congress hinged section 6015 jurisdiction on the taxpayer's election of section 6015(b) or (c) relief, not the taxpayer's maintenance of eligibility for that relief. Thus, the Tax Court's jurisdictional approach remains within the letter of the statute. There have not yet been appellate decisions on this issue, and considering the IRS's acquiescence, there are unlikely to be any anytime soon. In addition, the Tax Court does have a track record of following its own rule in spite of reversal by one Court of Appeals, in cases where appeal lies to another Court of Appeals. ${ }^{329}$ Once again, reversal of the Tax Court may lie with Congress.

The Tax Court's power to apply such doctrines as equitable estoppel and equitable recoupment falls in a fourth category. This category reflects different considerations because the doctrines in question lack governing Code sections. It is the hardest group of doctrines for which to find authority to apply equity because the doctrines themselves are not statutory and the Tax Court's jurisdiction-granting provisions do not expressly provide for equity jurisdiction.

324. See IRC $\S 6015(\mathrm{e})$.

325. See supra note 268 and accompanying text.

326. See supra note 272 and accompanying text.

327. See supra note 276 .

328. Charlton v. Commissioner, 114 T.C. 333,339 n.2 (2000).

329. See, e.g., Estate of Branson v. Commissioner, 113 T.C. 6, 11 (1999) (applying equitable recoupment after Sixth Circuit reversal of Mueller); Estate of Bartels v. Commissioner, 106 T.C. 430, 433 (1996) (same); Estate of Orenstein v. Commissioner, 79 T.C. Memo (CCH) 1971, T.C. Memo (RIA) ๆ 2000-150 (same); Golsen v. Commissioner, 54 T.C. 742, 757 (1970) ("We shall remain able to foster uniformity by giving effect to our own views in cases appealable to courts whose views have not yet been expressed"), aff'd, on other grounds, 445 F.2d 985 (10th Cir. 1971), cert. denied, 404 U.S. 940 (1971). 
The best argument might be the historical lineage of tax refund actions, which may be traced back to the action of indebitatus assumpsit, an action tinged with equity. ${ }^{330}$

2. The Indebitatus Assumpsit Ancestry of Tax Refund Claims.-In 1934, the Supreme Court stated, "the statutes providing for refunds and for suits on claims therefor proceed on the same equitable principles that underlie an action in assumpsit for money had and received." "331 In 1937, the Court reiterated that statement, ${ }^{332}$ and further stated that a tax refund action,

although an action at law, is equitable in its function. It is the lineal successor of the common count in indebitatus assumpsit for money had and received. Originally an action for the recovery of debt, favored because more convenient and flexible than the common law action of debt, it has been gradually expanded as a medium for recovery upon every form of quasi-contractual obligation in which the duty to pay money is imposed by law, independently of contract, express or implied in fact. ${ }^{333}$

Although the Supreme Court is correct that the modern tax refund action developed out of the cause of action indebitatus assumpsit and has equitable aspects, the implication that assumpsit was an equitable cause of action (that is, cognizable by a court of equity) is misleading. In fact, as is discussed below, indebitatus assumpsit was actually a common law action with equitable aspects. ${ }^{334}$ According to the Supreme Court, because the tax refund action has an equitable pedigree, equity is relevant to disputes between taxpayers and the IRS over the taxpayer's correct tax liability. ${ }^{335}$

330. See infra text accompanying notes 397-402.

331. United States v. Jefferson Elec. Mfg. Co., 291 U.S. 386, 402 (1934). The common count of money had and received was one of several common counts in indebitatus assumpsit. See Arthur Allen Leff, The Leff Dictionary of Law: A Fragment, 94 Yale L.J. 1983, 2083 (1985) ("If one could not frame one's pleading so as to allege a sum certain owing to the plaintiff, one had available the 'common counts,' the most important of which (along with the 'debt' form for money had and received) were 'quantum meruit' and 'quantum velebant."').

332. Stone v. White, 301 U.S. 532, 535 (1937).

333. Id. at 534. In fact, indebitatus assumpsit was an action at law, not in equity. See infra notes 388-94 and accompanying text.

334. See infra notes 397-402 and accompanying text. Cf. Yung Frank Chiang, Payment by Mistake in English Law, 11 Fla. J. Int'1 L. 91, 97-98 (1996) ("In England, an action to recover payment for money had and received on the ground of mistake is within the jurisdiction of the court of law. Chancery, the equity court, never dealt with such action unless the plaintiff based the action on the fraud on the part of the defendant or unless the plaintiff, in an insolvency case, requested the court to distribute assets among claimants.").

335. Stone, 301 U.S. 532, 534 (1937). 
a. The Tax Refund Action and the Tax Court Overpayment Claim.-Historically, tax refund actions were suits brought against the tax collector because, until the Court of Claims was created in 1855, no suit of any kind against the United States government was permitted in any court. ${ }^{336}$ To allow recovery "without seeming to do violence to the sovereign's immunity from suit, ${ }^{\prime 337}$ in Elliott v. Swartwout, ${ }^{338}$ an 1836 case regarding customs duties, the Supreme Court sanctioned suits in assumpsit for money had and received against tax collectors for taxes collected illegally. ${ }^{339}$ "There money had been taken by the collector for duties which were not imposed. This money lawfully belonged to the plaintiff; it was the duty, therefore, of the collector to pay it back to him." 340

Although this type of suit against the tax collector was soon superseded in some cases by a statute requiring the duties to be paid over to the Treasury, and by the resulting administrative procedure, ${ }^{341}$ in 1866 , the Supreme Court held that the right to sue the tax collector with respect to internal revenue taxes was implicit in various assessment and collection statutes. ${ }^{342}$ That case was also an action in assumpsit for money had and received. ${ }^{343}$

The Supreme Court recognized that the suit against the tax collector was merely a mechanism to afford a remedy against the government. ${ }^{344}$ Once the Court of Claims was created, it afforded a forum for tax suits directly against the federal government. Yet, as discussed below, Congress and the courts seemed to deem important District Court jurisdiction over tax refund actions.

In 1887, Congress passed the Tucker Act, which gave the District Courts jurisdiction over all claims against the United States for damages up to $\$ 1,000$ that were founded upon the Constitution of the United States, any law of Congress, or any contract with the United States government. ${ }^{345}$ In 1911, the limitation on the amount of damages under the Tucker Act was increased to $\$ 10,000 .^{346}$ In 1915 , the Supreme Court held that the Tucker Act included

336. William T. Plumb, Jr., Tax Refund Suits Against Collectors of Internal Revenue, 60 Harv. L. Rev. 685, 687 (1947).

337. Id. at 688.

338. 35 U.S. 137 (1836).

339. Plumb, supra note 336, at 687; see Elliott, 35 U.S. 137 (1836).

340. Cary v. Curtis, 44 U.S. 236, 250 (1845).

341. See Plumb, supra note 336, at 689; Cary, 44 U.S. at 251.

342. See Philadelphia v. The Collector, 72 U.S. 720, 730 (1866); Plumb, supra note 336 , at 690 .

343. Philadelphia v. The Collector, 72 U.S. at 727.

344. See Plumb, supra note 336, at 691; see also George Moore Ice Cream Co. v. Rose, 289 U.S. 373, 383 (1933) (referring to a suit against the tax collector as "merely a remedial expedient for bringing the Government into court.").

345. Act of Mar. 3, 1887, ch. 359, 24 Stat. 505.

346. Act of Mar. 3, 1911, ch. 231, § 24, 36 Stat. 1093. 
jurisdiction over suits for tax refunds. ${ }^{347}$ Suits in District Court against the tax collector remained available for cases involving more than the capped amount. In 1935-1938, for example, suits against the collector comprised about $40 \%$ of tax refund actions brought in District Court. ${ }^{348}$

In 1921, the Supreme Court held that actions against a tax collector were personal in nature, and therefore not maintainable against his successor in office. ${ }^{349}$ Thus, if the collector had died or retired, a taxpayer with a refund claim of more than $\$ 10,000$ had no remedy in a District Court. Although the Claims Court option remained available, the Revenue Act of 1921 preserved the District Court as a forum by allowing suits against the United States for tax refunds involving more than $\$ 10,000 .^{350}$ In 1954 , the $\$ 10,000$ cap on Tucker Act claims was eliminated. ${ }^{351}$

District Court jurisdiction in refund actions is now embodied in 28 U.S.C. $\S 1346(a)(1),{ }^{352}$ which provides:

The district courts shall have original jurisdiction, concurrent with the United States Claims Court [United States Court of Federal Claims], of:

(1) Any civil action against the United States for the recovery of any internal-revenue tax alleged to have been erroneously or illegally assessed or collected, or any penalty claimed to have been collected without authority or any sum alleged to have been excessive or in any manner wrongfully collected under the internal-revenue laws. ${ }^{353}$

The modern-day action grew out of the historic action in indebitatus assumpsit against the tax collector.

Just as the origins of the modern-day suit directly against the sovereign for refund of overpaid taxes may be traced to the indebitatus assumpsit action against the tax collector based on a promise implied in law to refund taxes collected erroneously, the overpayment suit in Tax Court may be traced to the same great-grandparents. Congress gave overpayment jurisdiction to the Board of Tax Appeals in $1926^{354}$ for two reasons: (1) so that the Board would not lose jurisdiction over a case in which the taxpayer paid the deficiency prior to entry

347. United States v. Emery, Bird, Thayer Realty Co., 237 U.S. 28 (1915).

348. Roger J. Traynor, Administrative and Judicial Procedure for Federal Income, Estate, and Gift Taxes-A Criticism and a Proposal, 38 Colum. L. Rev. 1393, 1404 n.21 (1938).

349. Smietanka v. Indiana Steel Co., 257 U.S. 1 (1921).

350. See Revenue Act of 1921, ch. 136, $\$ 1310$ (c), 42 Stat. 311.

351. See Act of July 30, 1954, ch. 648, § 1, 68 Stat. 589.

352. Flora v. United States, 362 U.S. 145, 189 (1960).

353. 28 U.S.C. $\$ 1346(a)(1)$.

354. Revenue Act of 1926, ch. 27, \$ 284(e), 44 Stat. 67. The Board of Tax Appeals did not become a court until 1969. See Tax Reform Act of 1969, Pub. L. No. 91-172, § 951, 83 Stat. 487,730 . 
of its decision, ${ }^{355}$ and (2) so that if the taxpayer not only contested the deficiency but also claimed an overpayment for the same type of tax for the tax year, litigation in two courts could be avoided. ${ }^{356}$ Initially, the Supreme Court determined that the Board's overpayment jurisdiction did not allow it to order a refund after finding that the taxpayer had made an overpayment:

When the determination of overpayment by the Board becomes final, the statute provides that such amounts shall be refunded or credited, $\S 322$ (d), and upon the Commissioner's failure to comply with the statute, a plenary suit will lie in the district court or the Court of Claims, for the recovery of any refund to which he is entitled. ${ }^{357}$

The Supreme Court later found that, "the Commissioner may secure a final adjudication of his right to withhold the overpayment determined by the Board, on the ground that other taxes are due from the taxpayer, or that upon other grounds he is not equitably entitled to the refund." 358 Code section 6512(b)(2), which allows the Tax Court to order a refund, ${ }^{359}$ was enacted in $1988,{ }^{360}$ to avoid the necessity of duplicative litigation.

If the Court of Federal Claims has equitable powers over refund actions in that court, the next question is whether the Tax Court similarly has equitable powers over overpayment claims. Like the refund courts' jurisdiction over refund claims, ${ }^{361}$ the Tax Court's overpayment jurisdiction is statutory. ${ }^{362}$ Courts have distinguished the two types of courts' jurisdiction, but their focus on comparing deficiency and refund cases may be misleading. For example, in Estate of Mueller v. Commissioner, the Sixth Circuit stated:

A deficiency redetermination sought in the Tax Court should not be confused with a refund suit filed in the district court. Whereas the deficiency redetermination is nothing more than the judicial review of an assessment made by an administrative agency, a refund suit is an "action brought to recover a tax

355. See Harold Dubroff, The United States Tax Court: An Historical Analysis, $42 \mathrm{Alb}$. L. Rev. 353, 372 (1978). This issue is now specifically resolved by statute. See IRC $§ 6213$ (b)(4) ("In any case where [an] amount is paid after the mailing of a notice of deficiency under section 6212, such payment shall not deprive the Tax Court of jurisdiction over [the] deficiency determined under section $6211 \ldots$. .').

356. See Dubroff, supra note 355 , at 373.

357. United States ex rel. Girard Trust Co. v. Helvering, 301 U.S. 540, 542 (1937).

358. Id.

359. See IRC § 6512(b)(2).

360. Pub. L. No. 100-647 § 6244(a).

361. See 28 U.S.C. $\$ 1346(a)(1)$.

362. See IRC $\S 6512(b)$. 
erroneously paid, [which] although an action at law is equitable in its function. It is the lineal successor of the common count indebitatus assumpsit for money had and received." $" 363$

This statement says nothing about the origins or nature of the overpayment suit in Tax Court. In fact, overpayment suits function just like refund suits. The difference is that the Tax Court only has jurisdiction over overpayment suits in cases in which the IRS has alleged a deficiency. ${ }^{364}$ In other respects, overpayment suits and refund suits are virtually indistinguishable. In both cases, the taxpayer will have already paid the tax in question. ${ }^{365}$ The statutory periods of limitation will be the same, ${ }^{366}$ although, primarily as a result of the lack of necessity for a refund claim, ${ }^{367}$ the time periods will not always run at the same time. ${ }^{368}$

Another apparent, but misleading, difference between the refund courts and the Tax Court lies in the burden of proof. As discussed above, ${ }^{369}$ in the absence of the application of a statutory burden of proof rule, ${ }^{370}$ the burdens of proof have been analyzed differently in the two types of courts. ${ }^{371}$ In refund courts, the taxpayer bears a two-part burden: proving the government wrong, and establishing the amount owed him. ${ }^{372}$ In a deficiency case in Tax Court, the taxpayer need not prove a dollar amount. The explanation for this distinction between the burden of proof in refund courts and in Tax Court rests on the indebitatus assumpsit origins of the refund suit. ${ }^{373}$ However, for this purpose,

363. Estate of Mueller, 153 F.3d at 304 (emphasis added) (quoting Stone v. White, 301 U.S. 532 (1937)).

364. See IRC $\S 6512(b)$. In other words, if the taxpayer simply discovers that he overpaid his taxes, his only potentially available fora are the District Courts and the Court of Federal Claims.

365. In refund courts, Flora v. United States, 362 U.S. 145 (1960), requires full payment as a condition of suit. In the Tax Court, an overpayment claim may only be made with respect to tax already paid. See IRC $\$ 6512$.

366. See IRC $\$ 6511$.

367. See IRC $\S 6512$ (b)(3) (providing time periods that refer to $\S 6511$ and generally correspond to time period that would be applicable in refund court suits).

368. See Commissioner v. Lundy, 516 U.S. 235 (1996). For analysis of the problems created by the complications of $\S 6512$, particularly with respect to delinquent returns, see, e.g., Leandra Lederman, It's Time to Fix the "Traps for the Unwary" in the Refund Statutes, 79 Tax Notes 1057 (1998); Leandra Lederman, Applying the Refund Statutes to Delinquent Returns. 68 Tax Notes 1639 (1995).

369. See supra note 312 and accompanying text, supra notes $316-18$ and accompanying text.

370. See IRC $\$ \S 7454$ (burden of proving fraud is on the IRS). 7491 (burden shifts to IRS when taxpayer meets certain threshold requirements).

371. See supra notes $316-18$ and accompanying text.

372. See, e.g., United States v. Janis, 428 U.S. 433, 440 (1976); Bar L Ranch, Inc. v. Phinney, 426 F.2d 995, 999 (5th Cir. 1970).

373. See, e.g., Leo P. Martinez, Tax Collection and Populist Rhetoric: Shifting the 
the burden in refund courts should be compared with the burden in overpayment cases, not the burden in deficiency cases. With respect to overpayments, the taxpayer does have to prove the amount he overpaid. Thus, with respect to taxpayer claims of entitlement to a refund, the two types of fora would seem to have the same requirements.

Thus, overpayment jurisdiction and the ability to order refunds are statutorily created in the Tax Court, much like the refund actions justiciable in the District Courts and the Court of Federal Claims are created by statute. As the discussion above reflects, overpayment suits are modeled after refund suits. Accordingly, like the refund suit, the overpayment suit may trace its origins back to the indebitatus assumpsit action.

b. The Quasi-Equitable Historyof Indebitatus Assumpsit.-The term "indebitatus assumpsit" is Latin for "being indebted, he promised,"374 reflecting the idea of an existing indebtedness followed by a promise by the debtor to the creditor to repay the debt. The assumpsit action developed because of the common law courts' need for an action that did not suffer from the constraints of the actions for debt and for covenant. The action for debt required an exact sum due and quid pro quo. ${ }^{375}$ In addition, "wager of law," in which the defendant brought to court "oath helpers" who affirmed that no debt was owed, allowing the defendant to prevail, was available as a defense to informal (unsealed) contracts. ${ }^{376}$ The action for covenant would lie for breach of promise, but only for promises under seal. ${ }^{377}$

Because of the inflexibility of the actions of debt and covenant, the Court of Chancery began to countenance actions not allowed in the common law. ${ }^{378}$ In response, the common law courts began to expand the tort action of trespass, which alleged a wrong done against the peace of the king, into trespass on the case, in which the king had no special interest. ${ }^{379}$ Over time, a trespass action became available to a plaintiff alleging that the defendant had not kept his covenant. ${ }^{380}$ "By the late fourteenth century, the undertaking, 'assumpsit,' had become the contractual basis for recovery."

Burden of Proof in Tax Cases, 39 Hastings L.J. 239, 262 (1988); Bar L Ranch, Inc. v. Phinney, 426 F.2d 995, 999 (5th Cir. 1970).

374. Leff, supra note 331 , at 2083.

375. James Oldham, Reinterpretations of 18th-Century English Contract Theory: The View from Lord Mansfield's Trial Notes, 76 Geo. L.J. 1949, 1950, 1953 (1988).

376. See id. at 1950 n.24; Leff, supra note 331, at 2083.

377. Leff, supra note 331, at 2083.

378. Oldham, supra note 375, at 1953.

379. Id. at 1953-54.

380. Id. at 1955 (quoting Milsom, supra note 96 , at 322 ).

381. Id. 
In 1602 , Slade's Case ${ }^{382}$ extended the assumpsit action from failure to perform an action promised to failure to pay an amount promised. ${ }^{383}$ In effect, Slade's Case allowed a plaintiff to plead assumpsit "when what had really happened is that the defendant had received something which he ought to pay for, but had not in fact promised to do so, either at the time of the transaction or thereafter. ${ }^{1384}$ The term indebitatus assumpsit has been used to describe the action permitted in Slade's Case although in fact the term was not used until $1657 .^{385}$

In 1760, in Moses v. Macferlan, ${ }^{386}$ Lord Mansfield, the Chief Justice of the Court of King's Bench, ${ }^{387}$ allowed an action of indebitatus assumpsit for money had and received where no contract existed and the plaintiff alleged that he had made payment by mistake. ${ }^{388}$ This allowed the law to develop so that, although indebitatus assumpsit required that a promise be alleged ${ }^{389}$ the promise did not need to be proven. ${ }^{390}$ In addition, though indebitatus assumpsit originally applied only to contracts implied-in-fact, it was later extended to contracts implied-in-law (or "quasi-contracts"), that is, obligations created by law, such as taxes. ${ }^{391}$ Courts addressed the illogic of finding a subsequent promise in a contract only implied by law by finding that "the law implied a promise."392 This allowed the extension of the indebitatus assumpsit doctrine to its eventual use to obtain a refund of taxes illegally or erroneously collected.

The common counts in indebitatus assumpsit, which reflected the nature of the underlying obligation, arose out of standardization of pleading in the seventeenth century. ${ }^{393}$ The common counts in indebitatus assumpsit included money had and received, money paid, quantum meruit and quantum

382. 76 Eng. Rep. 1074 (1602).

383. Oldham, supra note 375, at 1957 (quoting J.H. Baker, An Introduction to English Legal History 282 (2d ed. 1979)).

384. Leff, supra note 331, at 2083.

385. Chiang, supra note 334 , at 97 n.39.

386. 97 Eng. Rep. 676 (K.B. 1760).

387. Oldham, supra note 375 , at 1949.

388. Chiang, supra note 334, at 97 n.39 (1996); cf. Ramsay v. County of Clifton, 92 III. 225, 228-29 (1879) (refusing to grant bill in equity for mistake because "the action at law for money had and received is ... a full and complete remedy") (cited in Val D. Ricks, American Mutual Mistake: Half-Civilian Mongrel, Consideration Reincarnate, 58 La. L. Rev. 663, 731 n.361).

389. William A. Keener, Quasi-Contract, Its Nature and Scope, 57, 66 (1893); see also Cary v. Curtis, 44 U.S. 236, 250 (1845) ("This promise [to pay] is always charged in the declaration, and must be so charged in order to maintain the action.").

390. See Oldham, supra note 375, at 1957.

391. J. B Ames, The History of Assumpsit, 2 Har. L. Rev. 53, 63, 65 (1888), (citing City of London v. Goree, 1 Vent. 298).

392. Keener, supra note 389 , at 66 .

393. See James Oldham, Reinterpretations of 18th-Century English Contract Theory: The View from Lord Mansfield's Trial Notes, 76 Geo. L.J. 1949, 1957 (1988). 
velebat. ${ }^{394}$ It is the common count of money had and received (essentially a debt action) ${ }^{395}$ that underlies the modern tax refund action. ${ }^{396}$

An erroneous link of indebitatus assumpsit to equity apparently arose from a misinterpretation of Moses v. Macferlan. ${ }^{397}$ In that case, Lord Mansfield found that the plaintiff had the equities on his side, referring to "ties of natural justice and equity to refund the money,"398 and allowed an indebitatus assumpsit action for money had and received to lie where no actual contract, express or implied, existed. ${ }^{399}$ The reference to equity may have caused an inference that indebitatus assumpsit was an action available in courts of equity, rather than courts at law. ${ }^{400}$ Thus, American courts have made such statements as:

According to the modern doctrine, there is no difference at law or in equity with respect to [the defendant's] liability. The action for money had and received ... is an equitable action, and is held to lie wherever money has been paid to the use of another, which, ex equo et bono, he ought to refund. The defence allowed to this action is equally liberal, every thing being permitted to be given in evidence... which may tend to destroy or diminish the equity of the plaintiff's claim. ${ }^{401}$

However, as Peter Birks has persuasively argued, Lord Mansfield's equity reference was to Roman aequitas (fairness), not chancery. ${ }^{402}$

394. See supra note 331, at 2083; Mitchell McInnes, The Canadian Principle of Unjust Enrichment: Comparative Insights into the Law of Restitution, 37 Alberta L. Rev. 1, 18 (1999).

395. See Leff, supra note 331, at 2083.

396. See supra note 179 and accompanying text; supra note 331 and accompanying text. 397. 97 Eng. Rep. 676 (K.B. 1760).

398. Id. at 681 .

399. See Mark P. Gergen, The Jury's Role in Deciding Normative Issues in the American Common Law, 68 Fordham L. Rev. 407, 485 n.308 (1999); Ricks, supra note 388, at 731; Chiang, supra note 334, at 103.

400. See Ricks, supra note 388 , at 732 n.369.

401. Dupuy v. Johnson, $4 \mathrm{Ky} .562$ (1809) (emphasis added); see also Keyes v. First Nat. Bank, 25 F.2d 684, 688 (8th Cir. 1928) ("The action of assumpsit for money had and received is equitable in its essential nature and purpose. It lies for money which ex aequo et bono the defendant ought to refund."); Ricks, supra note 388, at 732-33.

"Ex aequo et bono" means something like "in faimess and justice." See, e.g., Keyes, 25 F.2d at 694 n.142. Courts tend to use this phrase in connection with determining the taxpayer's equitable rights in an action in indebitatus assumpsit. See, e.g., Herrmann v. Gleason, 126 F.2d 936, 939 (6th Cir. 1942) ("Where one has in his hands money which, according to the rules of equity and good conscience, ought to be paid to another, assumpsit is the proper form of remedy; and if, at the time of commencement of action, a party holds money which, ex aequo et bono, he ought not to have retained from plaintiffs, they are entitled to recovery.").

402. Peter B.H. Birks, English and Roman Learning in Moses v. Macferlan, 37 Current Legal Problems 1, 21 (1984). 
The fairness-based "equitable" character of the assumpsit action is evident in statements in some American decisions. For example, the Tax Court has stated, "[a]n action in assumpsit for money had and received is equitable in character and lies, in general, whenever a defendant has received money that in equity and good conscience he ought to pay to plaintiff." ${ }^{403}$ The Court of Federal Claims stated, "[a]n action for refund of taxes is essentially governed by equitable principles ... equity is woven into the warp and woof of a refund suit ...."404 That is, the refund action does have an equity-based flavor. This analysis arguably might allow equitable defenses such as equitable recoupment to apply absent a statutory prohibition - though the connection with true equity is weak. For example, if a taxpayer claimed an income tax overpayment in Tax Court (after receiving a notice of deficiency for that tax year) and the IRS responded by raising the specter of a deficiency in gift tax for a barred year, ${ }^{405}$ the assumpsit line of reasoning might allow the IRS to raise the defense of equitable recoupment.

Unfortunately, in each of the four recent cases in which the Tax Court applied equitable recoupment, the taxpayer had not made an overpayment claim. ${ }^{406}$ The cases were deficiency cases before the Tax Court; overpayments

403. Estate of Mueller v. Commissioner, 101 T.C. 551, 566 n.2 (1993) (citing Black's Law Dictionary 112 (5th ed. 1979)).

Because in an assumpsit action "the plaintiff must recover by virtue of a right measured by equitable standards, it follows that it is open to the defendant to show any state of facts which, according to those standards, would deny the right . ..." Stone, 301 U.S. at 535.

404. Erickson v. United States, 309 F.2d 760, 763 (Ct. Cl. 1962). Cf. Steuerwald v. Richter, 158 Wis. 597, 604 (1914) (I would not speak of the right to money had and received as an equitable right, nor of the remedy to enforce it, as in its nature equitable, nor the form of the action as legal; but that the primary right is a creation of equity, the right to enforce it is a legal right the same as in case of any other legal obligation ....").

Currently, the right to a trial by jury in tax refund suits in the District Courts is provided by statute. See 28 U.S.C. $\$ \$ 1346$ (a)(1), 2402. The Seventh Amendment guarantees the right to a jury trial "in suits at common law." See U.S. Const. amend. VII. The common law referenced is that of England as of 1791. Baltimore \& Carolina Line, Inc. v. Redman, 295 U.S. 654, 657 (1935). There is some disagreement over whether the Seventh Amendment protects the right to trial by jury in a tax refund suit. Compare Beard v. Commissioner, 99-2 U.S. Tax Cas. (CCH) If 50,677, 84 A.F.T.R. 2d 99-5058 (6th Cir. 1999) (finding no such right because "no right of action at common law existed against a sovereign.") with United States v. New Mexico, 642 F.2d 397,401 (10th Cir. 1981) (reviewing legislative history of 28 U.S.C. $\$ 2402$ to find that "the 1954 congressional action is a reaffirmation of the common law recognition of the right to jury trial."); cf. Wickwire v. Reineke, 275 U.S. 101, 105. However, in neither case did the courts contrast common law rights with rights in equity.

405. For example, if, in Year 5, a taxpayer timely seeks a refund for Year 2, the taxpayer's equitable right "ex aequo et bono" to the refund should be lost if the taxpayer has a deficiency for Year 1 that is barred by the statute of limitations on assessment. Although the statute of limitations on assessment bars the government from pursuing the Year 1 tax deficiency, the presence of that deficiency would render it inequitable for the taxpayer to collect a refund from the government.

406. See supra notes 160-233 and accompanying text, (discussing Mueller, Orenstein, Bartels, and Branson, all deficiency cases). 
arose with respect to related transaction in a barred year only after the Tax Court had decided the deficiency issues. ${ }^{407}$ In each case, the taxpayers could not make an overpayment claim because of the bar of the statute of limitations on refund claims. ${ }^{408}$ Although the Tax Court can consider tax years not before it in order to redetermine the tax deficiency for the tax year that is before it, ${ }^{409}$ that is not what the Tax Court did in these cases. The court did not need to consider other tax years or other taxes in order to compute the amount of the deficiency in the years before it. ${ }^{410}$ Therefore, absent jurisdiction over the other taxes and tax years, it lacked the power to consider the equitable recoupment claim.

The statute of limitations on refund claims is apparently a jurisdictional bar; section 6512(b)(1) provides:

Except as provided by paragraph (3) and by section 7463, if the Tax Court finds that there is no deficiency and further finds that the taxpayer has made an overpayment of income tax for the same taxable year, of gift tax for the same calendar year or calendar quarter, of estate tax in respect of the taxable estate of the same decedent, ... the Tax Court shall have jurisdiction to determine the amount of such overpayment, and such amount shall, when the decision of the Tax Court has become final, be credited or refunded to the taxpayer. ${ }^{411}$

Paragraph (3) of section 6512(b) provides limitations on the amount of credit or refund to be allowed, requiring timeliness in order for any amount to be refunded or credited. ${ }^{412}$ Accordingly, the Tax Court did not have jurisdiction to

407. See supra notes $160-233$ and accompanying text.

408. See supra notes $160-233$ and accompanying text; IRC $\S 6512(b)(3)$.

409. See IRC \$ 6214(a).

410. See Estate of Mueller, 101 T.C. at 566 (Tannenwald, J., dissenting).

411. IRC § 6512(b)(1) (emphasis added).

412. See IRC $\$ 6512(\mathrm{~b})(3)$. It provides, in relevant part:

(3) No such credit or refund shall be allowed or made of any portion of the tax unless the Tax Court determines as part of its decision that such portion was paid-

(A) after the mailing of the notice of deficiency,

(B) within the period which would be applicable under section 6511(b)(2), (c), or (d), if on the date of the mailing of the notice of deficiency a claim had been filed (whether or not filed) stating the grounds upon which the Tax Court finds that there is an overpayment, or

(C) within the period which would be applicable under section 6511(b)(2), (c), or (d), in respect of any claim for refund filed within the applicable period specified in section 6511 and before the date of the mailing of the notice of deficiency-

(i) which had not been disallowed before that date,

(ii) which had been disallowed before that date and in

respect of which a timely suit for refund could have been commenced as of that date, or

(iii) in respect of which a suit for refund had been 
consider the merits of the overpayment claim. Without considering the merits, the Tax Court could not determine whether an overpayment in fact existed.

This result is unfortunate in that (1) a federal District Court would have the power to consider the taxpayer's equitable recoupment arguments, and (2) arguably, given the equity-based origins of the overpayment claim, the Tax Court might have the authority to consider equitable recoupment arguments made by the government in overpayment cases. The Tax Court's tendency to "do equity" in difficult cases is understandable, but "hard cases make bad law."413 A solution lies with Congress; it should amend the Tax Court's jurisdiction-granting statutes to allow recoupment. Absent such an amendment, Tax Court should not engage in jurisdictional "self help." 414

Application of equitable estoppel or judicial estoppel is not limited by statute, unlike equitable recoupment, but its application also is not authorized by statute, as is equitable tolling, for example. ${ }^{415}$ In addition, equitable estoppel and judicial estoppel arguments may be raised in deficiency cases that do not involve an overpayment claim. Therefore, routine application of these and similar doctrines depends on finding a source of equitable power outside both the jurisdictional statutes and the quasi-equitable pedigree of the overpayment suit.

\section{CONCLUSION}

The powers of Article I courts are necessarily more circumscribed than those of their cousin courts granted power under Article III. Yet, Article I courts play a critical role in determining public rights such as the application of federal tax laws. Therefore, it is important to understand the extent of Article I courts' powers.

The question of the role that equity plays or should play in Article I courts has received little attention. Article I courts such as the Tax Court were unaffected by the merger of law and equity in the Federal Rules of Civil Procedure, and Congress did not grant the Tax Court general or specific equitable powers when it created the court. ${ }^{416}$ In fact, the Supreme Court has

commenced before that date and within the period specified in section $6532 . .$.

Id.

413. Northern Sec. Co. v. United States, 193 U.S. 197, 400 (1904) (Holmes, J., dissenting).

414. See Donald Black \& M.P. Baumgartner, On Self-Help in Modern Society, in The Manners and Customs of the Police 193, 193 n.3 (Donald Black ed., 1980) ("defining 'self-help' as a response to offensive behavior in which offended party takes action on his or her own") (cited in Marc Galanter \& David Luban, Poetic Justice: Punitive Damages and Legal Pluralism, 42 Am. U. L. Rev. 1393, 1399 n.15 (1993)).

415. See IRC $\S 6511(\mathrm{~h})$.

416. See IRC $\S \S 6511,6512$; cf. supra notes $36-44$ and accompanying text. 
stated that the Tax Court lacks equitable power. It is true that the Tax Court has no general reservoir of equitable powers on which it may draw when it sees fit; Article I of the Constitution does not provide that, and Congress did not supply it $^{417}$

Nonetheless, the Tax Court has been applying equitable doctrines when necessary to avoid harsh statutory results. This article has shown that the Tax Court lacks the authority to apply many of these doctrines. Public choice insight into judges' maximization of their power may help explain the Tax Court's application of equity in spite of the strictures of Article I of the Constitution. In addition, part of the Tax Court's temptation to "do equity" may result from the specter of outcomes inconsistent with similar cases brought in district court. ${ }^{418}$ That is a genuine problem, particularly because the Tax Court hears about $95 \%$ of litigated federal tax cases. ${ }^{419}$ But the reality is that, when Congress provided a pre-assessment tax forum, it did not give it jurisdiction coextensive with the jurisdiction of the district courts and the Court of Federal Claims. ${ }^{420}$

As tempting as it is to view the three federal tax fora as functionally indistinguishable (except when forum shopping), that simply is not the case. ${ }^{421}$ In fact, courts have ruled over and over that due process does not require access to the Tax Court. ${ }^{422}$ Due process does not require similar outcomes, either. ${ }^{423}$ It is simply considered the taxpayer's choice whether to seek refuge in the Tax Court or instead to pursue refund litigation, despite the practical reality that many people cannot afford to pay the asserted deficiency in full up front. ${ }^{424}$

Congress may enlarge the Tax Court's equity arsenal simply by enacting appropriate statutes, subject to the limits on separation of powers. Congress could also reconstitute the Tax Court as an Article III court. ${ }^{425}$ Alternatively, Congress could overrule Flora' $^{4}{ }^{426}$ full-payment rule to provide increased access to the federal district courts, which, under Article III, may

417. See U.S. Const. art. I; IRC $\$ \S 6511,6512$.

418. See supra note 301 and accompanying text.

419. See Lederman, supra note 145 , at 185 .

420. See IRC $\$ \S 6511,6512$.

421. See supra notes $305-18$ and accompanying text.

422. See supra note 319 and accompanying text.

423. See supra notes 301-319 and accompanying text.

424. See Flora, 357 U.S. at 75 ("It is suggested that a part-payment remedy is necessary for the benefit of a taxpayer too poor to pay the full amount of the tax. Such an individual is free to litigate in the Tax Court without any advance payment. Where ... for some . . . reason a suit in the District Court seems more desirable, the requirement of full payment may in some instances work a hardship.").

425. See Geier, supra note 30; cf. Judicial Conference of the United States, Report of the Federal Courts Study Committee 69 (Apr. 2, 1990) (suggesting that Congress create an Article III appellate division of the Tax Court with exclusive jurisdiction over most federal tax appeals, and provide exclusive trial-level jurisdiction in such cases to an Article I division of the court). 426. See Flora v. United States, 362 U.S. 145, 189 (1960). 
exercise the full array of equitable powers. ${ }^{427}$ Any of those options would resolve the constitutionally based problem facing the Tax Court when it uses equitable doctrines to achieve fair outcomes. However, they would not address the similar situations of other Article I courts. It is time for Congress to act so that courts such as the Tax Court will not exceed the constitutional limits on their powers.

427. See U.S. Const. art. III. $\S 2$, cl. 1 ("The judicial Power of the United States, shall be vested in one supreme Court, and in such inferior Courts as the Congress may from time to time ordain and establish. ...").

This last option would likely result in some shift of tax case filings from Tax Court to the District Courts, an occurrence that might not be desired by either forum. 


$$
\text { . }
$$

